BÁO CÁO CHUYÊN ĐỀ

\title{
Vai trò của rừng ngập mặn trong việc hỗ trợ ngành vận tải biển thực hiện cam kết bảo vệ môi trường và phát triển bền vững
}

Phạm Thu Thủy

Nguyễn Thị Vân Anh

Nguyễn Thị Thủy Anh

Tăng Thị Kim Hồng

Đặng Hải Phương
Nguyễn Thị Kiều Nương

Đặng Lê Hoa

Phạm Thị Thuyền

Hoàng Tuấn Long 



\section{Vai trò của rừng ngập mặn trong việc hỗ trợ ngành vận tải biển thực hiện cam kết bảo vệ môi trường và phát triển bền vững}

Phạm Thu Thủy

Tổ chức Nghiên cứu Lâm nghiệp Quốc tế (CIFOR)

Nguyễn Thị Vân Anh

VNU - Đại học Khoa học xã hội và nhân văn

Nguyễn Thị Thủy Anh

Học viện Ngoại giao

Tăng Thị Kim Hồng

Trường Đại học Nông Lâm TP.HCM (NLU)

Đặng Hải Phương

Trường Đại học Nông Lâm TP.HCM (NLU)

Nguyễn Thị Kiều Nương

Trường Đại học Nông Lâm TP.HCM (NLU)

Đặng Lê Hoa

Trường Đại học Nông Lâm TP.HCM (NLU)

Phạm Thị Thuyền

Trường Đại học Nông Lâm TP.HCM (NLU)

Hoàng Tuấn Long

Tổ chức Nghiên cứu Lâm nghiệp Quốc tế (CIFOR) 
Báo cáo chuyên đề 223

C 2021 Tổ chức Nghiên cứu Lâm nghiệp Quốc tế (CIFOR)

(c) (i) Nội dung trong ấn phẩm này được cấp quyền bởi Giấy phép bản quyền Ghi nhận công của tác giả - Phi thương mại, không chỉnh sửa, thay đổi hay phát triển - Không phát sinh 4.0. http://creativecommons.org/ licenses/by-nc-nd/4.0/

ISBN: 978-602-387-160-5

DOI: $10.17528 /$ cifor/008096

Phạm TT, Nguyễn TVA, Nguyễn TTA, Tăng TKH, Đặng HP, Nguyễn TKN, Đặng LH, Phạm TT và Hoàng TL. 2021. Vai trò của rừng ngập mặn trong việc hỗ trợngành vận tải biển thực hiện cam kết bảo vệ môi trường và phát triển bền vưng. Báo cáo chuyên đề 223. Bogor, Indonesia: CIFOR.

Trường Đại học Nông Lâm TP.HCM

Cảng Quốc tế Tân cảng - Cái Mép và Khu dự trữ sinh quyển rừng ngập mặn Cần Giờ

\section{CIFOR}

Jl. CIFOR, Situ Gede

Bogor Barat 16115

Indonesia

$\mathrm{T}+62$ (251) 8622-622

$\mathrm{F}+62(251) 8622-100$

E cifor@cgiar.org

\section{cifor.org}

Chúng tôi xin cảm ơn các nhà tài trợ đã hỗ trợ cho nghiên cứu này thông qua việc đóng góp vào quỹ của CGIAR. Xin xem danh sách các nhà tài trợ: http://www.cgiar.org/about-us/our-funders/

Tất cả các quan điểm thể hiện trong ấn phẩm này là của các tác giả. Chúng không nhất thiết đại diện cho quan điểm của CIFOR, các cơ quan chủ quản của tác giả hay của các nhà tài trợ cho ấn phẩm này. 


\section{Mục lục}

Lời cảm ơn $\quad$ v

Danh mục từ viết tắt $\quad$ vi

Tóm tắt tổng quan vii

1 Giới thiệu 1

2 Phương pháp nghiên cứu $\quad 2$

3 Vai trò và đóng góp của ngành vận tải biển đối với sự phát triển kinh tế 3

4 Tác động của ngành vận tải biển đối với môi trường và xã hội 4

5 Các giải pháp và đề xuất giúp ngành vận tải biển giảm phát thải, bảo vệ môi
trường và phát triển bền vững

5.1 Các giải pháp chính sách 9

$\begin{array}{ll}5.2 \text { Các giải pháp kinh tế và thị trường } & 16\end{array}$

$\begin{array}{ll}5.3 \text { Các giải pháp kỹ thuật } & 17\end{array}$

$\begin{array}{ll}5.4 \text { Các giải pháp xã hội } & 19\end{array}$

6 Vai trò của rừng ngập mặn trong việc hỗ trợ ngành vận tải biển và vận tải biển giảm phát thải, bảo vệ môi trường và phát triển bền vững 20

7 Kết luận 22

Tài liệu tham khảo $\quad 23$ 


\section{Danh mục bảng và hình}

\section{Bảng}

1 Tỷ trọng hàng hóa và mức phát thải của các loại hình tàu chở hàng khác nhau 5

2 Các quy định quốc tế về việc giảm phát thải đối với ngành vận tải biển 9

3 Các quy định và chính sách có liên quan đến ngành vận tải biển Việt Nam. 15

4 Vai trò và tiềm năng của rừng ngập mặn trong việc giải quyết các tác động tiêu của của ngành vận tải biển đối với môi trường

Hình

1 Tác động của ngành vận tải biển đối với môi trường và xã hội 4

2 Các giải pháp thích ứng và giảm thiểu biến đổi khí hậu đối với ngành vận tải biển $\quad 8$

3 Chi phí liên quan tới các hoạt động vận tải biển 16

4 Vai trò của rừng ngập mặn đối với ngành vận tải biển 20 


\section{Lời cảm ơn}

Nghiên cứu này được tài trợ bởi Cơ quan Hợp tác Phát triển $\mathrm{Na}$ Uy (NORAD), Cơ quan Phát triển Hoa Kỳ (USAID) và Chương trình Nghiên cứu CGIAR về Rừng, Cây xanh và Nông Lâm kết hợp (CRPFTA). Chúng tôi xin cảm ơn Bộ Nông Nghiệp và Phát Triển Nông Thôn (MARD) đã hỗ trợ nhóm nghiên cứu trong quá trinh nghiên cứu. Chúng tôi cũng gửi lời cảm ơn chân thành tới Cảng vụ Hàng hải Thành Phố Hồ Chí Minh, đại diện các hãng tàu và một số bên liên quan trong ngành vận tải biển đã tham gia hỗ trợ nghiên cứu này. 


\section{Danh mục từ viết tắt}

CRP-FTA

CSR

DPF

EEA

EEDI

ETS

EU

HFO

KNK

IMO

MARPOL

MGO

RNM

SEEMP

USAID
Chương trình Nghiên cứu CGIAR về Rừng, Cây xanh và Nông Lâm kết hợp Trách nhiệm xã hội của doanh nghiệp

Bộ lọc hạt động cơ diesel

Khu vực Kinh tế Châu Âu

Chỉ số hiệu quả năng lượng

Hệ thống thương mại khí thải của EU

Liên minh Châu Âu

Dầu nhiên liệu nặng

Khí nhà kính

Tổ chức Hàng hải Quốc tế

Công ước Quốc tế về Ngăn ngừa Ô nhiễm từ Tàu

Dâu khí biển

Rừng ngập mặn

Kế hoạch quản lý hiệu quả năng lượng tàu

Cơ quan Phát triển Hoa Kỳ 


\section{Tóm tắt tổng quan}

Với tốc độ và ảnh hưởng của biến đổi khí hậu ngày một gia tăng, Ủy ban Liên Hợp Quốc về biến đổi khí hậu cũng như các quốc gia trên thế giới đang kêu gọi sự tham gia tích cực của mọi ngành nghể để giải quyết vấn đề môi trường toàn cầu. Đóng vai trò chủ đạo trong thương mại thế giới khi vận chuyển $90 \%$ hàng hóa trên toàn câu, ngành vận tải biển có khả năng đóng góp vào cuộc chiến thích ứng và giảm thiểu tác động của biến đổi khí hậu.

Báo cáo này tìm hiểu những đóng góp cho sự phát triển kinh tế toàn câu và Việt Nam của ngành vận tải biển, phân tích tác động môi trường mà các hoạt động vận tải biển có thể gây ra, rà soát các giải pháp toàn câu và Việt Nam đang đưa ra để giải quyết các vấn đề rủi ro môi trường. Đông thời, báo cáo xem xét vai trò của rừng ngập mặn trong việc hỗ trợ ngành vận tải biển thực hiện các cam kết bảo vệ môi trường và phát triển bền vững.

Báo cáo chỉ ra rằng vận tải biển đóng vai trò quan trọng trong việc tạo công ăn việc làm và nâng cao giá trị GDP trên toàn cầu. Tuy nhiên, các hoạt động kinh doanh vận tải biển có thể gây ra ô nhiễm không khí, ô nhiễm nước, ô nhiễm tràn dầu, ô nhiễm tiếng ôn, làm xói mòn và sụt lún bờ biển đông thời ảnh hưởng nghiêm trọng tới sức khỏe của con người. Để ngăn chặn và giải quyết các rủi ro về vấn đề này, cộng đông quốc tế và các quốc gia (trong đó có Việt Nam) đã xây dựng và thực thi nhiều chính sách và sáng kiến quốc tế cũng như các giải pháp kỹ thuật đổi mới công nghệ. Tuy nhiên trong 5 năm trở lại đây, các chính sách đã chuyển từ chỗ chỉ tập trung vào những vấn đề kỹ thuật sang kết hợp giữa các giải pháp kỹ thuật, tài chính, xã hội, chính sách và sinh thái. Các giải pháp được đưa ra đều có những ưu điểm và hạn chế, do vậy việc kết hợp nhiều giải pháp sẽ giúp ngành vận tải biển nâng cao hiệu quả thực hiện cam kết bảo vệ môi trường, giảm chi phí vận hành và tạo hình ảnh thân thiện với môi trường nhằm đáp ứng nhu câu của thị trường và khách hàng.

Là hệ sinh thái có bể chứa Các-bon lớn nhất trên toàn cầu, rừng ngập mặn không chỉ được coi là một giải pháp sinh thái tiềm năng hỗ trợ ngành vận tải biển thực hiện các cam kết bảo vệ môi trường và phát triển bền vững mà còn nhận được sự quan tâm của xã hội. Tuy nhiên, thông tin về tầm quan trọng của rừng ngập mặn với việc đảm bảo hoạt động kinh doanh của ngành vận tải biển chưa thực sự được phổ biến đến nhiều doanh nghiệp trong ngành. Các nghiên cứu thực nghiệm về cơ chế tài chính cho đóng góp của ngành vận tải biển với việc bảo tồn rừng ngập mặn còn rất hạn chế.Vì vậy, cần có nhiểu nghiên cứu khoa học và chính sách mới thúc đẩy và nâng cao đóng góp của các ngành nghê, trong đó có ngành vận tải biển trong việc tạo ra cơ chế tài chính bền vững nhằm bảo vệ và phát triển rừng ngập mặn trong tương lai. 



\section{Giới thiệu}

Trước bối cảnh toàn thế giới đang tích cực tham gia vào cuộc chiến chống biến đổi khí hậu và áp lực từ yêu câu của khách hàng đối với các dịch vụ thân thiện với môi trường ngày càng tăng, ngành vận tải biển quốc tế nói chung và tại Việt Nam nói riêng đã xây dựng và triển khai nhiều giải pháp bảo vệ môi trường và phát triển bền vững trong 5 năm trở lại đây (Bowers 2021a). Cùng với các giải pháp kỹ thuật, cộng đồng quốc tế, khối tư nhân và các nhà tài trợ cũng đang hướng tới các giải pháp sinh thái để hỗ trợ ngành vận tải biển giảm phát thải và thực hiện cam kết về phát triển bền vững. Cụ thể hơn, các quốc gia đang phát triển, trong đó có Việt Nam đã nhấn mạnh mối liên kết và sự tương tác giữa ngành vận tải biển và hệ sinh thái rừng ngập mặn cũng như vai trò của rừng ngập mặn trong việc hạn chế sự nóng dân lên của trái đất (Ocean Economist 2021), giúp ngành vận tải biển trong việc đạt mục tiêu giảm phát thải, giảm chi phí bỏ ra cho nạo vét luông lạch, lưu giữ kim loại nặng trong nước, tạo vẻ đẹp cảnh quan, chắn sóng và giảm ô nhiễm tiếng ồn (Phạm và cộng sự 2019). Nhiêu chính sách mới được ra đời như Đề án Cảng xanh hay
Chính sách Chi trả dịch vụ môi trường rừng càng khẳng định sự quan tâm của Chính quyền trung ương và địa phương đối với sự phát triển bên vững, đảm bảo đạt mục tiêu kép về phát triển kinh tế và bảo vệ môi trường của ngành vận tải biển.

Trong khi phần lớn các báo cáo hiện nay tập trung vào việc phân tích các bài học kinh nghiệm trong áp dụng giải pháp kỹ thuật để hỗ trợ ngành vận tải biển đạt mục tiêu bảo vệ môi trường và phát triển bền vững, báo cáo này rà soát nhiêuu giải pháp khác được các bên liên quan đưa ra, trong đó có giải pháp dựa vào hệ sinh thái rừng ngập mặn đông thời phân tích thuận lợi và khó khăn trong việc thực hiện các giải pháp đó. Nhóm tác giả hi vọng báo cáo này sẽ cung cấp thông tin đầu vào hữu ích cho Bộ Giao thông và Vận tải trong quá trình hiện thực và đa dạng hóa các giải pháp được đề ra trong Đê án Cảng xanh và cho Bộ Nông nghiệp và Phát triển Nông thôn trong quá trình xây dựng chính sách chi trả dịch vụ môi trường rừng áp dụng với rừng ngập mặn. 


\section{Phương pháp nghiên cứu}

Báo cáo này được thực hiện dựa trên việc lược khảo tài liệu thứ cấp. Nhóm nghiên cứu rà soát lại các báo cáo thường niên, báo cáo định kỳ của các doanh nghiệp vận tải biển trên toàn câu, Tổ chức hàng hải quốc tế (IMO), các quy định chính sách vể biến đổi khí hậu của nhiều quốc gia, báo cáo khoa học trong và ngoài nước nhằm trả lời 4 câu hỏi chính sau đây :

i. Ngành vận tải biển đã và đang đóng góp cho sự phát triển kinh tế toàn câu và Việt Nam như thế nào?

ii. Ngành vận tải biển gây ra những tác động nào tới môi trường và xã hội? iii. Đã có những chính sách, giải pháp và sáng kiến nào đã/đang và sẽ được xây dựng và thực hiện nhằm hỗ trợ ngành vận tải biển giải quyết các vấn đề môi trường hiện có và thực hiện cam kết phát triển bên vững một cách hiệu quả? Thuận lợi và khó khăn trong việc thực hiện các chính sách, giải pháp và sáng kiến này là gì?

iv. Rừng ngập mặn có vai trò gì trong việc hỗ trợ ngành vận tải biển thực hiện các cam kết bảo vệ môi trường và phát triển bền vững?

Nhóm nghiên cứu sẽ thảo luận từng câu hỏi trong phần dưới đây. 


\section{Vai trò và đóng góp của ngành vận tải biển đối với sự phát triển kinh tế}

Ngành vận tải biển đóng vai trò chủ đạo trong nền kinh tế toàn câuu bởi $90 \%$ hàng hóa luân chuyển trên thế giới là qua đường biển (Selin và Cowing 2018). Năm 2019, tổng giá trị của thương mại vận tải biển thế giới đã đạt hơn 14 nghìn tỷ đô la Mỹ (International Chamber of Shipping 2019). Trong 20 năm trở lại đây, đóng góp của ngành vận tải biển vào GDP toàn câu tăng $73 \%$ (Goodwin 2016), đông thời tạo ra hàng trăm triệu việc làm trên toàn thế giới. Tại Châu Âu, ngành vận tải biển cũng chiếm tới $75 \%$ thương mại bên ngoài của EU, 36\% dòng chảy thương mại nội khối EU, vận chuyển hơn 400 triệu lượt hành khách mỗi năm (Defour và Afonso 2020) và hỗ trợ khoảng 2,1 triệu việc làm (Government Europa 2020). Châu Á đã trở thành nơi quy tụ hơn 50\% khối lượng thương mại vận tải biển toàn câu. Trong năm 2019, chỉ riêng châu Á có $41 \%$ tổng lượng hàng xuất khẩu và $62 \%$ hàng nhập khẩu được xếp dỡ, vận chuyển bằng đường biển (United Nations 2020). Tại Việt Nam, ngành vận tải biển cũng đóng vai trò quan trọng trong sự phát triển kinh tế chung của cả nước (Truong 2000, Nguyen 2016). Giá trị sản lượng của ngành vận tải biển, dịch vụ cảng biển và đóng tàu đã liên tục tăng 22\%/năm trong thời điểm 2007 2010 và $13 \%$ trong giai đoạn 2011 - 2015 (Bộ Tài nguyên và Môi trường 2020). So với năm 2000, sản lượng hàng hóa thông qua cảng biển Việt Nam năm 2017 đã tăng 6 lân về tổng hàng từ 73 triệu tấn lên 442 triệu tấn và tăng 12,5 lần vê hàng container từ 1,1 triệu TEU lên 14,4 triệu TEU (PetroVietnam 2019). Dù chịu ảnh hưởng của đại dịch Covid 19, vận tải biển vẫn duy trì tăng trưởng. Trong 4 tháng đầu năm 2020, sản lượng hàng hóa bốc dỡ qua hệ thống cảng biển Việt Nam khoảng hơn 215,3 triệu tấn, tăng 4\% so với cùng kỳ năm 2019, trong đó hàng container khoảng 6,78 triệu tấn, tăng $12 \%$ so với cùng kỳ năm 2019 (Nguyen 2020). Kim ngạch xuất khẩu thông qua vận tải biển đạt 264.273 triệu USD năm 2019 cao hơn khoảng 102.208 triệu USD so với năm 2015. Phân lớn lượng hàng hóa được xuất khẩu sang thị trường Mỹ đạt kim ngạch 61.404 triệu USD, sang thị trường Trung Quốc đạt 41.434 triệu USD, sang thị phân các nước khác như Nhật Bản, Hàn Quốc, Hồng Kông khoảng 47.318 triệu USD (UNCTAD 2020). 


\section{Tác động của ngành vận tải biển đối với môi trường và xã hội}

Mặc dù ngành vận tải biển đã đem lại các lợi ích kinh tế lớn như đã trình bày ở phân trên, trong thực tế các hoạt động vận tải biển cũng tạo ra nhiêu ảnh hưởng tới môi trường và xã hội (Hình 1).

Ô nhiễm không khí: Nếu so sánh với các loại hình vận tải khác, vận tải bằng đường thủy thường được coi là phương thức tiết kiệm và phát sinh ít khí thải hơn. Ví dụ, tại Châu Âu, lượng khí thải của giao thông vận tải biển chỉ bằng $80 \%$ lượng khí thải do hàng không (quốc tế và nội địa) và chỉ bằng $15 \%$ lượng khí thải giao thông đường bộ (Shell Global 2020). Tuy nhiên, đây vẫn là một nguồn phát thải KNK và ô nhiễm không khí rất lớn, ảnh hưởng đến môi trường và sức khỏe con người.

Giao thông đường thủy tạo ra 3 loại khí thải chính: (i) $\mathrm{CO}_{2}$; (ii) Các-bon đen được tạo ra từ quá trình đốt cháy nhiên liệu vận tải biển chiếm $21 \%$ lượng khí thải tương đương $\mathrm{CO}_{2}$ từ tàu, và là chất thứ hai gây ra các tác động đến môi trường không khí biển sau Các-bon dioxide (Europe Oceana 2020) và (iii) các loại khí thải khác.

Lượng khí thải $\mathrm{CO}_{2}$ từ vận tải biển trên toàn thế giới tăng từ 2,76\% (962 triệu tấn) năm 2012 lên
$2,89 \%$ (1.056 triệu tấn) vào năm 2018 , và $3,1 \%$ vào năm 2020 (EC 2013, Reynolds 2019, Saul 2020, Bowers 2021c). Lượng khí thải $\mathrm{CO}_{2}$ liên quan của $\mathrm{EU}$ từ giao thông vận tải biển đật 144 triệu tấn vào năm 2019 (Defour và Afonso 2020). Lượng khí thải $\mathrm{CO}_{2}$ phụ thuộc vào một số yếu tố bao gồm kỹ thuật (ví dụ: thủy động lực học, máy móc, tuổi đời, kích thước), các thông số vận hành (ví dụ: quãng đường di chuyển, tốc độ vận hành, hàng hóa được vận chuyển, nhiên liệu sử dụng, điêu kiện thời tiết) và tốc độ tàu (EC 2020, Faber và cộng sự 2021). Các loại tàu chở hàng khác nhau (hiện đang chiếm 55\% tổng lượng phát thải $\mathrm{CO}_{2}$ của ngành vận tải) có mức phát thải khác nhau (Bảng 1).

Bảy loại tàu gồm tàu chở hàng rời, tàu chở dâu, tàu container, tàu chở hóa chất, tàu chở khí đốt hóa lỏng, tàu chở hàng tổng hợp và tàu chở hàng rời đông lạnh, chiếm khoảng $88 \% \mathrm{CO}_{2}$ phát thải toàn câu (Faber và cộng sự 2021).

Các-bon đen có ảnh hưởng nghiêm trọng tới sức khỏe con người gây ra bệnh hô hấp, tim mạch và ung thư đông thời là chất dẫn mang vào cơ thể con người nhiêu loại hóa chất có độc tính khác nhau. Các-bon đen thải ra ở Bắc Cực đã được phát hiện làm, bề mặt Bắc Cực ấm lên gần gấp 5

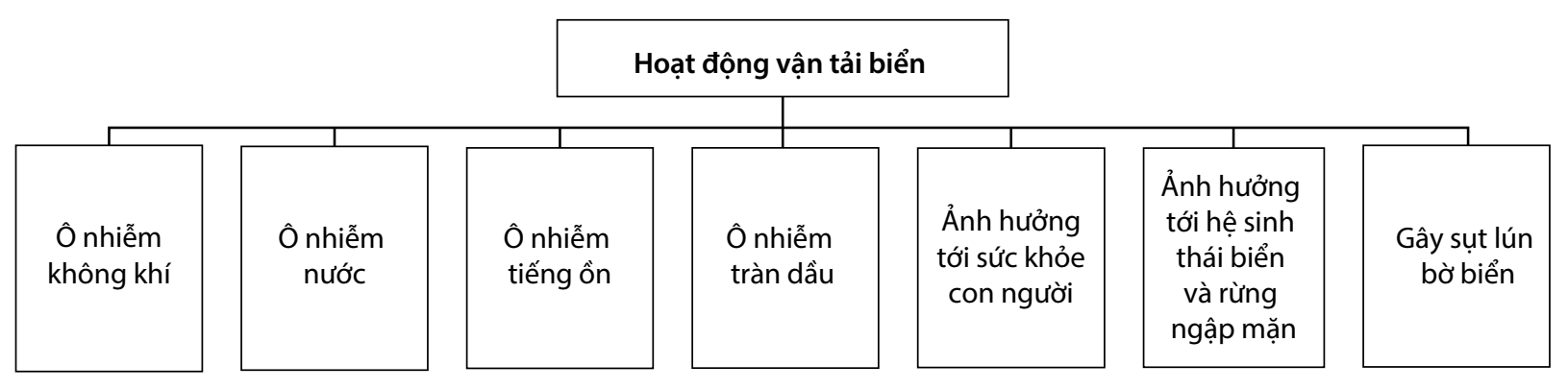

Hình 1. Tác động của ngành vận tải biển đối với môi trường và xã hội Nguồn: Nhóm tác giả tổng hợp (2021). 
Bảng 1. Tỷ trọng hàng hóa và mức phát thải của các loại hình tàu chở hàng khác nhau

\begin{tabular}{|c|c|c|}
\hline Loại hình vận tải & $\begin{array}{l}\text { Tỷ trọng hàng hóa/ } \\
\text { trọng tải tàu (\%) }\end{array}$ & \% tạo $\mathrm{CO}_{2}$ trong tổng lượng phát thải $\mathrm{CO}_{2}$ của ngành vận tải \\
\hline $\begin{array}{l}\text { Tàu hàng rời khô (dry } \\
\text { bulk carriers) vận chuyển } \\
\text { quặng sắt, than, ngũ } \\
\text { cốc và các loại hàng hóa } \\
\text { tương tự }\end{array}$ & 42,5 & $13 \%{ }^{a}-19 \%$ \\
\hline $\begin{array}{l}\text { Tàu chở dầu thô (oil } \\
\text { tankers) }\end{array}$ & 29,2 & 13 \\
\hline \multirow[t]{3}{*}{ Tàu container } & 13,1 & $23 \%-30 \%{ }^{b}$ \\
\hline & & $\begin{array}{l}\text { Lượng khí thải } \mathrm{CO}_{2} \text { từ } 17 \text { hãng vận tải container lớn nhất thế } \\
\text { giới, chiếm khoảng } 85 \% \text { lượng vận chuyển container toàn cầu } \\
\text { bao gồm AP Møller - Mærsk, CMA CGM Group, COSCO Shipping } \\
\text { Lines Ltd., Evergreen Line, Hapag-Lloyd, Hyundai MM, MSC, ONE } \\
\text { (Ocean Network Express) và Yang Ming Marine Transport Corp) } \\
\text { tiếp tục giảm vào năm 2019. Mức phát thải } \mathrm{CO}_{2} \text { trung bình trên } \\
\text { mỗi container trên km giảm lần lượt là 5,6\% và 2,5\% đối với chỉ } \\
\text { số Khô và Lạnh (làm lạnh) (CC 2019) }\end{array}$ \\
\hline & & $\begin{array}{l}\text { Sự cải thiện về chỉ số } \mathrm{CO}_{2} \text { đã được nhìn thấy ở các quốc gia } \\
\text { chính: } \\
\text { - Châu Á đến từ Bắc Âu với mức giảm } 3 \% \\
\text { - Châu Á đến từ Bờ Tây Bắc Mỹ và Châu Á đến từ Bờ Đông Bắc } \\
\text { Mỹ với mức giảm } 6 \% \text {, } \\
\text { - Châu Á đến từ Trung Đông / Ấn Đồ với mức giảm 12\% } \\
\text { - Châu Á đến từ Địa Trung Hải / Biển Đen với mức giảm 12\% }\end{array}$ \\
\hline
\end{tabular}

a Quãng đường di chuyển khoảng 55 triệu hải lý

b 1.742 con tàu di chuyển trên 70 triệu hải lý

Nguồn: CC 2019, EC 2020, Healy và Graichen 2019, Reynolds 2019, Ovcina 2020.

lần so với các-bon đen thải ra ở vĩ độ trung bình (Reynolds 2019). Giảm tốc độ tàu mà không điều chỉnh quá trình đốt cháy động cơ, có thể dẫn đến tăng hệ số phát thải Các-bon đen do quá trình đốt cháy kém hiệu quả. Giảm phát thải Các-bon đen ít nhất 35\% so với mức năm 2010 được cho là bắt buộc vào năm 2050 (IPCC 2018, Reynolds 2019).

Không chỉ tạo ra 3\% lượng khí thải $\mathrm{CO}_{2}$ trên toàn cầu, ngành vận tải biển còn tạo ra lượng khí thải metan tăng $150 \%$ trong giai đoạn 20112018 (Bowers 2020b), khoảng 15\% lượng khí thải oxit nitơ $\left(\mathrm{NO}_{\mathrm{x}}\right)$ và $5-8 \%$ lượng phát thải oxit lưu huỳnh $\left(\mathrm{SO}_{\mathrm{x}}\right)$ trên tổng lượng khí thải toàn câu (Frese 2019, Trimmer và Godar 2019) dẫn tới hư hại mùa màng, giảm tuổi thọ của các tòa nhà gây ra các vấn đề về hô hấp và đẩy cao nguy cơ bệnh tim mạch (Vidal 2009). Các động cơ diesel trên tàu lớn nhất thế giới thường hoạt động trong khoảng 280 ngày mỗi năm tạo ra khoảng 5.200 tấn $\mathrm{SO}_{\mathrm{x}}$ (Vidal 2009).

Với tốc độ tăng trưởng và thực trạng phát thải hiện nay, ngành vận tải biển có thể chịu trách nhiệm cho $10 \%$ tổng lượng phát thải trên toàn câuu vào năm 2030 (Abbasov 2020) và tăng $50 \%$ từ nay đến năm 2050 nếu không có biện pháp hiệu quả nào có thể ngăn chặn được điều này (Defour và $A$ fonso 2020). Với lượng khí thải tạo ra, ngành vận tải biển sẽ là một nguồn ô nhiễm không khí chính, có khả năng ảnh hưởng đến người dân ở các quốc gia dọc theo các tuyến đường vận chuyển, vì hầu hết khí thải được thải ra trong phạm vi $400 \mathrm{~km}$ tính từ bờ biển (Trimmer và Godar 2019).

Việc vận chuyển hàng hóa bằng đường biển tạo ra khoảng 300 triệu tấn nhiên liệu bẩn và do vậy có lượng khí thải Các-bon tương đương với tổng 
lượng phát thải của nước Đức (Selin và Cowing 2018). Trong thực tế, nếu vận tải biển toàn câu là một quốc gia, thì quốc gia đó sẽ là nhà sản xuất phát thải KNK lớn thứ sáu (Europe Oceana 2020). Chỉ riêng mười lăm con tàu lớn nhất đã gây ra ô nhiễm nhiều như tất cả 760 triệu chiếc ô tô trên toàn thế giới (Europe Oceana 2020, Helms 2013). Trên thế giới, Panama (15\%), Trung Quốc (11\%) và Liberia (9\%) là những nước phát thải từ ngành vận tải biển nhiều nhất (Frese 2019).

Mặc dù đã có nhiều quy định quốc tế và khu vực trong việc kiểm soát mức phát thải của ngành vận tải biển, lượng phát thải từ vận chuyển hàng hải hâuu như không được chú ý trong các cuộc thảo luận về giảm thiểu biển đổi khí hậu, về tiêu dùng và sản xuất bên vững (Trimmer và Godar 2019, Europe Oceana 2020, Defour và Afonso 2020). Việc theo dõi và giám sát phát thải của ngành vận tải biển không dễ dàng khi thiếu dữ liệu đáng tin cậy vể lượng khí thải đang được thải ra môi trường và còn nhiêu tranh cãi trong việc phân công trách nhiệm về lượng khí thải đó cho các quốc gia khác nhau, thương nhân, nhà sản xuất, người tiêu dùng và các công ty vận tải liên quan (Trimmer và Godar 2019). Đặc biệt, theo thông lệ, lượng phát thải trên mỗi loại hàng hóa được ước tính dựa trên khối lượng giao dịch của hàng hóa, bỏ qua các yếu tố cụ thể như khối lượng và độ cồng kềnh của hàng hóa và cách chúng được vận chuyển (ví dụ: loại tàu), có thể có ảnh hưởng đáng kể đến quy mô của khí thải (Trimmer và Godar 2019). Ngoài ra, do vận tải biển đóng một vai trò quan trọng trong nền kinh tế thế giới nên việc xây dựng các chính sách gặp phải nhiêu cản trở bởi các bên liên quan. Nhiêu học giả cũng cho rằng rất khó để dự đoán lượng phát thải $\mathrm{CO}_{2}$ từ vận tải biển trong tương lai vì điều này phụ thuộc nhiều vào nhu cầu vận chuyển quốc tế, sự sẵn có và tính hiệu quả của các giải pháp kỹ thuật và sự phát triển và thị trường của nhiên liệu thay thế, cũng như chi phí và lợi ích của các giải pháp này (Fenhann 2017).

Ô nhiễm tiếng ồn: Nhiều nghiên cứu đã chỉ ra rằng, vận tải đường thủy tạo ra ô nhiễm tiếng ôn ảnh hưởng tới sức khỏe của cộng đông dân cư sống gần tuyến giao thông đường thủy. Ngoài ra, cộng đông quốc tế và các quốc gia bày tỏ sự quan ngại lớn hơn trước vận tải đường thủy đặc biệt việc vận hành tàu biển qua các đại dương đã gây tổn hại đáng kể tới hệ sinh thái biển trên quy mô toàn cầu. Cụ thể hơn, các hoạt động này đã dẫn tới việc giảm số lượng cá thể và khả năng sinh nở của nhiều loại động vật biển quý hiếm (ví dụ: cá heo, cá voi, các loài sinh vật biển đang bị đe dọa và có khả năng bị tuyệt chủng) (Simpson và cộng sự 2010).

Ô nhiễm nước: Phạm và cộng sự (2020) đã chỉ ra rằng các hoạt động đóng tàu, hoạt động xả thải của tàu (ví dụ: nước thải, nước giảm khói bụi) đã làm nước biển bị ô nhiễm nặng và tại nhiêu nơi mức ô nhiễm đã vượt quá mức cho phép theo quy định của quốc gia và thế giới (Frese 2019, Abbasov 2020).

Ô nhiễm tràn dầu: Các hãng tàu và Ban quản lý cảng trên toàn thế giới đều ghi nhận tác động tiêu cực với môi trường nếu có sự cố tràn dầu xảy ra. Cũng bởi vậy, nhiều biện pháp đổi mới công nghệ và các mô hình bảo hiểm khắc phục hậu quả tràn đâu đã được đưa ra trên toàn câu (Reynolds 2019).

Ảnh hưởng tới sức khỏe con người: Vào năm 2015, ô nhiễm từ 90.000 tàu chở hàng trên thế giới dẫn đến 90.000 ca tử vong mỗi năm và tiêu tốn 330 tỷ Đô la Mỹ của xã hội để chữa các bệnh về phổi và tim mạch (Vidal 2009). Tại Đan Mạch, ô nhiễm từ vận chuyển đường thủy tiêu tốn của quốc gia này gần 5 tỷ bảng Anh mỗi năm, chủ yếu là điêu trị ung thư và các vấn đề về tim và 1.000 người tại đất nước này bị chết sớm mỗi năm vì ô nhiễm vận chuyển đường biển (Vidal 2009).

\section{Ảnh hưởng tới hệ sinh thái biển và rừng ngập mặn: Phạm và cộng sự $(2019,2020)$ đã chỉ ra rằng, việc xây dựng cảng biển, và tác động của các hoạt động vận chuyển đường thủy đã làm suy giảm cả về số lượng và chất lượng, diện tích và hệ sinh thái rừng ngập mặn trên toàn thế giới nói chung và Việt Nam nói riêng. Rừng ngập mặn có thể bị hủy hoại do các hoạt động dọn dẹp, lau chùi tàu hoặc khắc phục các hậu quả (Beyer và cộng sự 2016). Cây rừng bị chết làm giảm độ che phủ rừng do dầu bám dính vào rễ cây (Tam và cộng sự 2005). Việc dầu tràn lan nhanh trên mặt nước, một số hòa tan trong nước và chìm xuống}


đáy dẫn đến ô nhiễm trầm tích và ảnh hưởng rất lớn đến quần thể sinh vật (Beyer và cộng sự 2016). Levings và cộng sự (1997) cho rằng dâu nằm trong trầm tích ở nồng độ trên $100 \mu \mathrm{g} \mathrm{g}^{-1}$ trọng lượng khô sẽ gây ra các ảnh hưởng tiêu cực đối với cây rừng ngập mặn.
Xói lở và sụt lún bờ biển: Các hoạt động kinh doanh của vận tải biển và hoạt động nạo vét thường xuyên để duy trì luồng cho các tàu lớn ở vùng cửa sông đã dẫn đến xói lở và sụt lún bờ biển tại Việt Nam (Anthony và cộng sự 2015). Trong bối cảnh này, bảo vệ và trồng mới rừng ngập mặn luôn được coi là một trong các biện pháp ưu tiên (Viện Hàn lâm Khoa học và Công nghệ Việt Nam 2020). 


\section{Các giải pháp và đề xuất giúp ngành vận tải biển giảm phát thải, bảo vệ môi trường và phát triển bền vững}

Để có thể giảm thiểu rủi ro và tác động của ngành vận tải biển đối với môi trường và xã hội, cộng đồng quốc tế, Ủy ban Liên Hợp Quốc về Biến đổi khí hậu, $\mathrm{IMO}$ và các quốc gia đã đề ra nhiều giải pháp (Hình 2).

Sử dụng khí thiên nhiên hoá lỏng (LNG)

Nâng cao hiệu quả sử dụng năng lượng cho các tàu mới (EEDI)

Tàu điện và hạt nhân nguyên tử

Các hướng dẫn kỹ thuật và giảm tốc độ

Kế hoạch quản lý năng lượng hiệu quả (SEEMP)

Nhiên liệu sinh học hoặc các chất thay thế bao gồm hydro và amoniac

Chi trả dịch vụ môi trường rừng và hệ sinh thái

Thương mại khí thải phát thải KNK của ngành vận tải biển

Hình 2. Các giải pháp thích ứng và giảm thiểu biến đổi khí hậu đối với ngành vận tải biển

Nguồn: Nhóm tác giả tự tổng hợp, UNFCCC 2014, Shell và Deloitte
Trách nhiệm xã hội CSR

Các giải pháp xã hội
Han mức phát thải cho phép

Cơ chế giảm và thương mại khí thải bắt buộc đối với các hãng tàu

Hệ thống theo dõi, giám sát, thẩm định báo cáo phát thải

Cam kết kinh doanh không phá rừng 
Từng giải pháp và cách tiếp cận trong Hình 2 sẽ được nhóm nghiên cứu thảo luận chi tiết hơn trong các phân dưới đây.

\subsection{Các giải pháp chính sách}

Trước sức ép và tác động (tiêu cực) mà ngành vận tải biển tạo ra cho môi trường và xã hội, từ năm 1997 đã có nhiều chính sách, khung pháp lý và cam kết được đưa ra ở cấp độ toàn cầu và quốc gia.

\subsubsection{Quy định quốc tế}

Từ năm 1997 cho tới nay, các quy định quốc tế về giảm tác động môi trường và phát thải của ngành vận tải biển đã đạt được những bước tiến dài, chuyển mình từ việc chỉ khuyến khích các cam kết và đổi mới công nghệ sang một hệ thống pháp lý toàn diện giải quyết các vấn đề kinh tế, xã hội, môi trường và kỹ thuật khác nhau (Bảng 2).

Bảng 2. Các quy định quốc tế về việc giảm phát thải đối với ngành vận tải biển

\begin{tabular}{|c|c|c|}
\hline Năm & Tên quy định, khung pháp lí, cam kết & Chi tiết \\
\hline 1997 & Nghị định thư Kyoto 1997 & $\begin{array}{l}\text { Tổ chức Hàng hải Quốc tế (IMO) có nhiệm vụ xây dựng lộ } \\
\text { trình, chính sách giảm phát thải từ vận tải biển quốc tế }\end{array}$ \\
\hline 2009 & Chương trình nghị sự của MEPC & $\begin{array}{l}\text { Tác động về tiếng ồn từ vận chuyển hàng hải thương mại và } \\
\text { tác động bất lợi của các hoạt động này đối với sinh vật biển } \\
\text { đã được đưa vào thảo luận }\end{array}$ \\
\hline $\begin{array}{l}2011- \\
2013\end{array}$ & $\begin{array}{l}\text { IMO thông qua quy trình quản lý các } \\
\text { quy định về tiết kiệm năng lượng như là } \\
\text { những sửa đổi của Công ước Quốc tế về } \\
\text { Ngăn ngữa Ô nhiễm tữ Tàu (MARPOL) và } \\
\text { có hiệu lực từ ngày } 1 \text { tháng } 1 \text { năm } 2013\end{array}$ & $\begin{array}{l}\text { Hướng tới việc nâng cao hiệu quả sử dụng năng lượng của } \\
\text { vận tải biển quốc tế }\end{array}$ \\
\hline 2014 & $\begin{array}{l}\text { Hướng dẫn giảm thiểu tiếng ồn dưới } \\
\text { nước từ vận chuyển thương mại để giải } \\
\text { quyết các tác động bất lợi đến sinh vật } \\
\text { biển (MEPC.1 / Circ.833) }\end{array}$ & $\begin{array}{l}\text { Hướng dẫn không mang tính bắt buộc nhưng đưa ra lời } \\
\text { khuyên chung cho các nhà thiết kế, đóng tàu và khai thác } \\
\text { tàu thương mại trong việc cải thiện các yếu tố tạo ra tiếng ồn } \\
\text { như kết cấu cánh quạt, thiết kế thân tàu, máy móc trên tàu, } \\
\text { các biện pháp vận hành và bảo dưỡng }\end{array}$ \\
\hline 2015 & $\begin{array}{l}\text { Thỏa thuận Paris- Thỏa thuận của Liên } \\
\text { hợp quốc vể Biến đổi khí hậu (UNFCCC) }\end{array}$ & $\begin{array}{l}\text { Đây là thỏa thuận quốc tế về biến đổi khí hậu có tầm ảnh } \\
\text { hưởng đến nề kinh tế và vận hành của các ngành trên toàn } \\
\text { cầu từ nay cho tới năm } 2030 \text {. Các nước đã cam kết giảm phát } \\
\text { thải KNK để hạn chế sự gia tăng nhiệt độ trung bình toàn câuu } \\
\text { xuống dưới } 2^{\circ} \mathrm{C} \text { cao hơn mức thời kỳ tiên công nghiệp, và } \\
\text { theo đuổi nỗ lực hạn chế mức tăng lên } 1,5^{\circ} \mathrm{C} \text {, nhằm giảm rủi } \\
\text { ro và tác động của biến đổi khí hậu. Mặc dù trong thỏa thuận } \\
\text { này không ghi chi tiết rằng ngành vận tải biển phải cam kết } \\
\text { giảm phát thải nhưng việc các quốc gia cam kết giảm phát } \\
\text { thải từ mọi lĩnh vực cũng có nghĩa họ sẽ hiện thực hóa cam } \\
\text { kết này cho mọi ngành nghề, trong đó có vận tải biển. Ví dụ, } \\
\text { Liên minh châu Âu (EU) đã coi việc thực hiện giảm phát thải } \\
\text { trong ngành vận tải biển là một trong những giải pháp quan } \\
\text { trọng để thực hiện cam kết Thỏa thuận Paris của mình }\end{array}$ \\
\hline 2015 & $\begin{array}{l}\text { Quy định của hội đồng Châu Âu (EU) } \\
\text { 2015/757 ngày } 29 \text { tháng } 4 \text { năm } 2015 \text { về } \\
\text { giám sát, báo cáo và xác minh lượng khí } \\
\text { thải Các-bon dioxide từ giao thông vận } \\
\text { tải biển và sửa đổi Chỉ thị 2009/16 / EC }\end{array}$ & $\begin{array}{l}\text { Chỉ thị 2009/29/EC của Nghị viện Châu Âu và của Hội đồng } \\
\text { (3) và Quyết định số 406/2009/EC của Nghị viện và Hội đồng } \\
\text { Châu Âu (4) kêu gọi sự đóng góp từ tất cả các lĩnh vực của } \\
\text { nển kinh tế để đạt được giảm phát thải, bao gồm cả lĩnh vực } \\
\text { vận tải biển quốc tế. Tổ chức Vận tải biển Quốc tế (IMO) đưa } \\
\text { ra đề xuất đưa lượng khí thải vận tải biển quốc tế vào cam } \\
\text { kết giảm thiểu biến đổi khí hậu có hiệu lực vào năm } 2013\end{array}$ \\
\hline
\end{tabular}


Bảng 2. Tiếp trang trước

\begin{tabular}{|c|c|c|}
\hline Năm & Tên quy định, khung pháp lí, cam kết & Chi tiết \\
\hline & & $\begin{array}{l}\text { Quy định về hệ thống giám sát, báo cáo và xác minh (MRV) } \\
\text { minh bạch và công khai với công chúng về lượng khí thải } \\
\mathrm{CO}_{2} \text { dựa trên mức tiêu thụ nhiên liệu của tàu biển cùng với } \\
\text { phát thải từ các lĩnh vực khác đã và đang đóng góp vào cam } \\
\text { kết đó, đồng thời giảm các rào cản thị trường bằng cách } \\
\text { cung cấp thông tin đáng tin cậy về mức tiêu thụ nhiên liệu } \\
\text { và hiệu quả năng lượng cho các thị trường liên quan tữ đó } \\
\text { đưa ra các dữ liệu đáng tin cậy để đặt ra các mục tiêu giảm } \\
\text { phát thải chính xác và đánh giá tiến độ đóng góp của vận tải } \\
\text { biển nhằm đạt được nền kinh tế các-bon thấp. Với tính chất } \\
\text { quốc tế của vận tải biển, phương pháp ưu tiên và hiệu quả } \\
\text { nhất để giảm phát thải KNK trong vận tải biển quốc tế sẽ là } \\
\text { theo thỏa thuận toàn cầu }\end{array}$ \\
\hline 2016 & Sửa đổi MARPOL & $\begin{array}{l}\text { Để yêu cầu các tàu có tổng trọng tải từ } 5.000 \text { GT trở lên } \\
\text { (chiếm khoảng } 85 \% \text { lượng phát thải KNK từ tàu) thu thập và } \\
\text { gửi dữ liệu tiêu thụ dầu nhiên liệu từ } 1 \text { Tháng } 1 \text { năm } 2019 \text { để } \\
\text { tổng hợp và nộp cho IMO }\end{array}$ \\
\hline
\end{tabular}

2016 Tiêu chuẩn liên quan Tổ chức tiêu chuẩn
hóa quốc tế ISO 17208-1: 2016 Âm học
dưới nước

2016 Kế hoạch Quản lý Hiệu quả Năng lượng
Tàu (SEEMP)

- Áp dụng với các tàu có tổng dung tích từ 400 GT trở lên

- Yêu cầu tất cả các tàu, cả mới và hiện có, phải phát triển và duy trì Kế hoạch Quản lý Hiệu quả Năng lượng Tàu cụ thể trên tàu, để cải thiện hiệu quả năng lượng trên biển và trong cảng

- Hướng dẫn năm 2016 về Xây dựng Kế hoạch Quản lý Tiết kiệm Năng lượng Tàu (Nghị quyết MEPC.282 (70)) cung cấp Hướng dẫn về Thực hành Tốt nhất cho Hoạt động Tiết kiệm Nhiên liệu của Tàu nhưng không bao gồm các yêu cầu bắt buộc

2016 Thuế nhiên liệu đốt cháy do Quỹ Tiền tệ Quốc tế (IMF) và Tổ chức Hợp tác và Phát triển Kinh tế (OECD) đề xuất đánh thuế Các-bon đối với cả vận tải biển nhằm thực hiện thỏa thuận Paris

2016 Quy định thực hiện cam kết (EU) 2016/1928 ngày 4 tháng 11 năm 2016 về xác định hàng hóa được vận chuyển cho các loại tàu không phải là tàu chở khách, tàu ro-ro và tàu container theo Quy định (EU) 2015/757 của Nghị viện Châu Âu và của Hội đồng về giám sát, báo cáo và xác minh lượng khí thải Cácbon dioxide từ giao thông vận tải biển
Mức thuế 25 USD cho mỗi tấn $\mathrm{CO}_{2}$ đã được đề xuất. Một loại thuế như vậy sẽ kích thích đầu tư vào hiệu quả năng lượng, nhưng đề xuất này vẫn chưa được đưa vào chương trình nghị sự của IMO

Quy định này đưa ra các quy tắc xác định các thông số áp dụng để xác định hàng hóa được vận chuyển cho các loại tàu không phải là tàu chở khách, tàu ro-ro và tàu container nhằm mục đích giám sát các thông tin liên quan khác trên cơ sở mỗi chuyến đi theo Điều 9 (1) Quy định (EU) 2015/757. Trong trường hợp tàu chở dầu, tàu chở hóa chất, tàu chở khí, tàu chở hàng rời, tàu chở hàng lạnh và tàu chở hỗn hợp, cần đảm bảo rằng việc xác định chỉ số hiệu quả năng lượng hoạt động trung bình phù hợp với Hướng dẫn của IMO về việc sử dụng tự nguyện Chỉ số Vận hành Hiệu quả Năng lượng Tàu (EEOI) (2) vì các Hướng dẫn đó phản ánh các thông lệ trong ngành

Các thông số để xác định "hàng hóa được chuyên chở” trên mỗi loại tàu 
Bảng 2. Tiếp trang trước

Năm Tên quy định, khung pháp lí, cam kết Chi tiết

Hàng hóa được vận chuyển nhằm mục đích theo dõi các thông tin liên quan khác trên cơ sở mỗi chuyến đi theo Điều 9 (1) của Quy định (EU) 2015/757, sẽ được xác định như sau:

- Đối với tàu chở dầu, là khối lượng của hàng hóa trên tàu;

- Đối với tàu chở hóa chất, là khối lượng của hàng hóa trên tàu;

- Đối với tàu vận chuyển LNG, là khối lượng hàng hóa khi dỡ hàng, hoặc nếu hàng hóa được dỡ xuống nhiều lần trong một chuyến đi, tổng số hàng hóa được dỡ ra trong một chuyến đi và số hàng hóa được dỡ xuống tại tất cả các cảng ghé tiếp theo cho đến khi hàng hóa mới được chuyển tải lên tàu;

- Đối với tàu vận chuyển khí, như khối lượng của hàng hóa trên tàu;

- Đối với tàu chở hàng rời, như khối lượng của hàng hóa trên tàu;

- Đối với các tàu chở hàng tổng hợp, là trọng lượng chuyên chở cho các chuyến đi đầy hàng;

- Đối với tàu chở hàng lạnh, là khối lượng của hàng hóa trên tàu;

- Đối với tàu vận chuyển phương tiện, là khối lượng của hàng hóa trên tàu, được xác định là khối lượng thực tế hoặc bằng số lượng đơn vị hàng hóa hoặc số mét làn đường chiếm dụng nhân với các giá trị mặc định cho trọng lượng của chúng;

- Đối với tàu sân bay kết hợp, như khối lượng của hàng hóa trên tàu;

- Đối với tàu ro-pax, là số lượng hành khách và khối lượng hàng hóa trên tàu, được xác định bằng khối lượng thực tế hoặc số lượng đơn vị hàng hóa (xe tải, ô tô, v.v.) hoặc số mét làn đường chiếm dụng nhân với mặc định giá trị cho trọng lượng của chúng;

- Đối với tàu chở hàng container/ ro-ro, là khối lượng hàng hóa trên tàu, được xác định bằng tổng số đơn vị hàng hóa (ô tô, rơ moóc, xe tải và các đơn vị tiêu chuẩn khác) nhân với diện tích mặc định và với chiều cao của boong (khoảng cách giữa sàn và dầm kết cấu), của số làn đường chiếm dụng-mét nhân với chiều cao của boong (đối với hàng roro khác) và của số TEU nhân với 38,3 m³

2018 Chỉ đạo (EU) 2018/410 của bộ phận châu Âu và hội đồng ngày 14 tháng 3 năm 2018 sửa đổi Chỉ thị 2003/87/EC để tăng cường giảm phát thải hiệu quả và đầu tư các-bon thấp, và Quyết định (EU) 2015/1814
- Chỉ thị 2003/87/EC của Nghị viện Châu Âu và của Hội đồng (4) đã thiết lập một hệ thống giao dịch phát thải KNK trong Liên minh, nhằm thúc đẩy giảm phát thải KNK theo cách thức tiết kiệm và hiệu quả về mặt kinh tế

- Cơ chế thương mại phát thải của EU được đưa ra hướng tới đạt được mục tiêu đề ra trong Thỏa Thuận Paris vào năm 2030

- Các biện pháp hỗ trợ một số ngành công nghiệp sử dụng nhiều năng lượng có thể bị rò rỉ các-bon như được đề cập trong Điều 10a và $10 \mathrm{~b}$ của Chỉ thị 2003/87/EC cũng cần được xem xét dựa trên các biện pháp chính sách khí hậu ở các nền kinh tế lớn khác 
Bảng 2. Tiếp trang trước

\begin{tabular}{|c|c|}
\hline Năm & Tên quy định, khung pháp lí, cam kết \\
\hline $\begin{array}{l}2018- \\
2019\end{array}$ & $\begin{array}{l}\text { Giám sát, báo cáo và xác minh (MRV) } \\
\text { thông tin sẽ được thực hiện theo Quy } \\
\text { định 2015/757 (được sưa đổi bởi Quy } \\
\text { chế được sửa đổi 2016/2071) }\end{array}$ \\
\hline
\end{tabular}

\section{Chi tiết}

- Từngày 1 tháng 1 năm 2018, các tàu lớn trên 5.000 DWT tổng trọng tải đang bốc dỡ hàng hóa hoặc hành khách tại các cảng trong Khu vực Kinh tế Châu Âu (EEA) phải theo dõi và báo cáo lượng khí thải $\mathrm{CO}_{2}$ liên quan tới mức tiêu thụ nhiên liệu và các thông số khác, như quãng đường di chuyển, thời gian trên biển và hàng hóa được vận chuyển trên mỗi chuyến đi, để thu thập dữ liệu hàng năm vào một báo cáo khí thải được gửi cho người xác minh vận chuyển MRV được công nhận

- Từ năm 2019, trước ngày 30 tháng 4 hàng năm, thông qua THETIS MRV, các công ty sẽ đệ trình lên Ủy ban và các Quốc gia mà các tàu đó đã đăng ký ('các Quốc gia treo cờ') một báo cáo phát thải đã được xác minh mới có thể thực hiện các hoạt động vận tải biển trong Khu vực Kinh tế Châu Âu trong kỳ báo cáo trước (năm dương lịch)

- Từ năm 2019, trước ngày 30 tháng 6 hàng năm, các công ty phải đảm bảo rằng tất cả các tàu của họ đã thực hiện các yêu cầu trong kỳ báo cáo trước đó và đang cập các cảng trong Khu vực Kinh tế Châu Âu phải mang theo tài liệu tuân thủ do THETIS MRV cấp. Nghĩa vụ này có thể phải chịu sự kiểm tra của các cơ quan chức năng của các Quốc gia Thành viên. Hàng năm, Ủy ban công bố một báo cáo để thông báo cho công chúng về lượng khí thải $\mathrm{CO}_{2}$ của ngành

2018 Ủy ban Bảo vệ Môi trường Biển (MPEC) của Tổ chức Vận tải biển Quốc tế (IMO)

- Trong chiến lược ban đầu, mức độ tham vọng giảm phát đã thông qua 'Chiến lược IMO ban đầu về [giảm] phát thải KNK từ tàu thuyền' thải KNK từ vận tải biển quốc tế ít nhất là $50 \%$ vào năm 2050 so với năm 2008

- Việc giảm phát thải $\mathrm{CO}_{2}$ sẽ được tính cho từng hoạt động vận tải trung bình trong toàn hệ thống vận tải quốc tế sẽ phải giảm tối thiểu 40\% vào năm 2030, 70\% vào năm 2050 so với năm 2008

- Sử dụng tối ưu hóa tốc độ và giảm tốc độ làm thước đo, có tính đến các vấn đề an toàn, khoảng cách di chuyển, sự biến dạng của thị trường hoặc thương mại và để biện pháp đó không ảnh hưởng đến khả năng của tàu vận chuyển để phục vụ các khu vực địa lý khác nhau trên toàn cầu

- Mặc dù điều này không có tính ràng buộc, IMO dự kiến sẽ thực hiện các biện pháp cụ thể hơn vào năm 2023. IMO là cơ quan quản lý đầu tiên áp dụng tham vọng toàn cầu cho toàn bộ ngành công nghiệp có tầm quan trọng thiết yếu trong nền kinh tế toàn cầu này (Shell và Deloitte 2020)

2019 Chỉ số Thiết kế Hiệu quả Năng lượng (EEDI)
- Áp dụng cho tất cả các tàu có tổng dung tích từ 400 GT trở lên

- Yêu cầu các tàu mới phải tuân thủ các mức hiệu suất hiệu quả năng lượng bắt buộc tối thiểu, tăng dần theo thời gian qua các giai đoạn khác nhau. Các sửa đổi đối với MARPOL Phụ lục VI nhằm tăng cường các yêu cầu bắt buộc về hiệu quả năng lượng hiện có (EEDI) đối với một số loại tàu mới sau đó đã được phê duyệt vào tháng 5 năm 2019 để thông qua tại MEPC 75 vào tháng 4 năm 2020 
Bảng 2. Tiếp trang trước

\begin{tabular}{|c|c|c|}
\hline Năm & Tên quy định, khung pháp lí, cam kết & Chi tiết \\
\hline & & $\begin{array}{l}\text { - Chỉ số yêu cầu các tàu mới phải trở nên tiết kiệm năng } \\
\text { lượng hơn, với các tiêu chuẩn sẽ ngày càng được thực hiện } \\
\text { nghiêm ngặt hơn theo thời gian. Các hạng tàu và kích cớ } \\
\text { tàu khác nhau sẽ có các tiêu chuẩn khác nhau để đáp ứng. } \\
\text { Các tiêu chuẩn được so sánh với đường cơ sở, được đặt làm } \\
\text { hiệu suất trung bình của các tàu được đóng từ năm 1999- } \\
2009 \text {. Giai đoạn I: mục tiêu cải thiện tổng thể 10\% về hiệu } \\
\text { suất năng lượng trên tàu áp dụng cho các tàu đóng mới } \\
\text { từ năm } 2015 \text { đến năm } 2019 ; \text { Giai đoạn Il: các tàu đóng từ } \\
\text { năm } 2020 \text { đến năm } 2024 \text { sẽ phải cải thiện hiệu suất năng } \\
\text { lượng từ } 15 \text { đến } 20 \% \text {, tùy thuộc vào loại tàu; Giai đoạn Ill: } \\
\text { Các tàu được giao sau năm } 2025 \text { sẽ phải đạt hiệu suất cao } \\
\text { hơn } 30 \% \text {. Các tàu nhỏ hơn có các yêu câuu vể hiệu quả khác } \\
\text { nhau cho mỗi giai đoạn }\end{array}$ \\
\hline
\end{tabular}

2019 Thỏa thuân Xanh châu Âu (Bowers 2020a)
Thỏa thuận Xanh Châu Âu là một tập hợp các sáng kiến chính sách của Ủy ban Châu Âu với mục tiêu bao trùm là làm cho khí hậu Châu Âu trở nên trung hòa vào năm 2050. Cam kết đưa khí thải của ngành vận tải vào ETS

Thỏa thuận này bao gồm một gói biện pháp đầy tham vọng để chuyển đổi $E U$ thành một nền kinh tế bền vững bằng cách biến những thách thức về khí hậu và môi trường thành cơ hội trên tất cả các lĩnh vực chính sách và làm cho quá trình chuyển đổi công bằng và bao trùm tất cả mọi người. Thỏa thuận Xanh Châu Âu yêu cầu tất cả các lĩnh vực đều phải thể hiện vai trò của mình trong việc giảm phát thải, bao gồm cả lĩnh vực vận tải biển

2019 Hệ thống thương mại khí thải của EU (ETS)
Người gây ô nhiễm (bao gồm ngành vận tải biển) sẽ phải trả tiền. Nói cách khác, các con tàu sẽ phải trả mức phí phạt cho mỗi tấn $\mathrm{CO}_{2}$ thải ra, dựa trên mức tiêu thụ nhiên liệu đã báo cáo theo quy định của MRV

Quy định của EU yêu cầu tất cả các tàu trên 5.000 DWT phải báo cáo mức tiêu thụ nhiên liệu hàng năm và lượng khí thải $\mathrm{CO}_{2}$ liên quan của tàu khi (không) bốc hàng hoặc hành khách vì lý do thương mại. Các khí thải:

- Từ các chuyến đi giữa các cảng trong Khu vực Kinh tế Châu Âu (EEA)

- Từ các chuyến đi giữa cảng cuối cùng không thuộc $E E A$ và cảng tiếp theo nằm trong $\mathrm{EEA}$

- Từ các chuyến đi giữa cảng $E E A$ cuối cùng và cảng tiếp theo cảng không thuộc EEA và khi tàu ở bến

- Lượng khí thải $\mathrm{CO}_{2}$ được xác định dựa trên lượng nhiên liệu tiêu thụ kết hợp với hệ số phát thải $\mathrm{CO}_{2}$ cụ thể của nhiên liệu

- Phạm vi chính sách này cho phép MRV bao gồm khoảng $90 \%$ tổng lượng khí thải $\mathrm{CO}_{2}$ vận tải biển của $\mathrm{EU}$, trong khi chỉ bao gồm khoảng 55\% tổng số tàu ghé vào các cảng của EEA 
Bảng 2. Tiếp trang trước

\begin{tabular}{|c|c|c|}
\hline Năm & Tên quy định, khung pháp lí, cam kết & Chi tiết \\
\hline & & $\begin{array}{l}\text { - Mỗi năm một lần, các công ty vận tải hoạt động trên các } \\
\text { tuyến đường vận chuyển của Liên minh Châu Âu phải tổng } \\
\text { hợp dữ liệu của họ và nhờ các cơ quan xác minh độc lập } \\
\text { xác minh trước khi đệ trình lên Ủy ban Châu Âu. Sau đó, Ủy } \\
\text { ban công bố hẩu hết các dũ liệu đã được xác minh này và } \\
\text { chuẩn bị một báo cáo hàng năm để thông báo cho công } \\
\text { chúng và các tổ chức Châu Âu khác }\end{array}$ \\
\hline $\begin{array}{l}2021- \\
2022\end{array}$ & & $\begin{array}{l}\text { Nghị viện Châu Âu đã thông qua dự thảo luật bao gồm } \\
\text { lượng khí thải từ tàu vào ETS tứ ngày } 1 \text { tháng } 1 \text { năm } 2022 \\
\text { trong khi Ủy ban đã đưa ra sáng kiến đổi mới ETS và mở } \\
\text { rộng phạm vi của nó sang ngành vận tải biển. Sáng kiến } \\
\text { hiện đang trong giai đoạn tham vấn cộng đồng, kết thúc vào } \\
\text { ngày } 5 \text { tháng } 2 \text { năm } 2021 \text { (Hargreaves 2021) }\end{array}$ \\
\hline
\end{tabular}

Nguồn: EU 2016, Fenhann 2017, Reynolds 2019, Defour và Afonso 2020, EC 2020

Tổ chức Vận tải biển Quốc tế (IMO) hiện yêu câuu các tàu phải giảm $10 \%$ lượng khí thải 5 năm một lần cho đến năm 2030 và các tàu đóng mới sau năm 2025 phải tiết kiệm năng lượng hơn 30\% so với các tàu đóng năm 2014. Ủy ban Châu Âu cũng đang yêu câu thay đổi thông qua Sách trắng Giao thông vận tải năm 2013, trong đó đặt mục tiêu giảm lượng khí thải xuống 40-50\% so với mức năm 2005, đồng thời yêu cầu giảm lượng Nitơ oxit $\mathrm{NO}_{\mathrm{x}}$ và các hạt oxit lưu huỳnh $\left(\mathrm{SO}_{\mathrm{x}}\right)$ từ khí thải của tàu.

Cùng với những quy định quốc tế nêu trên, các cường quốc và Châu lục trên toàn thế giới cũng nâng cao tính chặt chẽ trong khuôn khổ pháp lý về bảo vệ môi trường trong ngành vận tải biển. Ví dụ, cả Châu Âu và Mỹ đều xây dựng các chính sách phát triển khu vực phát thải thấp ngay xung quanh các bờ biển của mình, nhằm đảm bảo sức khỏe con người và môi trường của đất nước họ (Vidal 2009). Áp lực cũng đang gia tăng đối với Tổ chức Vận tải biển Quốc tế và $E U$ trong việc thắt chặt luật quản lý khí thải của tàu sau quyết định của chính phủ Mỹ áp đặt một vùng đệm nghiêm ngặt dài 230 dặm dọc theo toàn bộ bờ biển Hoa Kỳ theo như mô hình của Canada (Vidal 2009). Vương quốc Anh tiên phong trong khối EU khi đưa lượng khí thải hàng không và vận tải quốc tế vào ngân sách các-bon quốc gia khi tuyên bố sẽ cắt giảm $78 \%$ lượng khí thải vào năm 2035 (Bowers 2021c).

Các hiệp hội ngành nghề cùng với khối tư nhân trong nhiêu năm qua cũng đã tích cực chủ động thực hiện nhiêuu biện pháp giảm phát thải. Hội đông Vận tải biển Thế giới và các công ty thành viên cũng đang tham gia vào nhiều nỗ lực nhằm giảm lượng $\mathrm{CO}_{2}$ và nâng cao hơn nữa hiệu quả trên toàn đội tàu thông qua các biện pháp tiết kiệm nhiên liệu, giới thiệu các tàu mới, lớn hơn và hiệu quả hơn, giảm tốc độ và sửa đổi kỹ thuật cho các tàu hiện có. Dưới_áp lực của thế giới và khách hàng, nhiều tập đoàn vận tải biển lớn trên thế giới đã phải thực hiện những cam kết giảm biến đổi khí hậu. Ví dụ, tập đoàn vận tải biển khổng lồ Maersk Lines của Đan Mạch tuyên bố sẽ vận hành tàu chở hàng trung hòa Các-bon đầu tiên trên thế giới vào năm 2030 nhưng dưới áp lực của khách hàng họ đã phải cam kết rút ngắn 7 năm để đưa sản phẩm vận hành vào năm 2023 (Bowers 2021b). Các hãng tàu này cũng hướng tới sử dụng "methanol trung tính Các-bon" bằng sinh học (Bowers 2021b).

\subsubsection{Chính sách tại Việt Nam}

Trong 5 năm trở lại đây, cộng đồng quốc tế đã ghi nhận sự quan tâm của Chính phủ Việt Nam trong việc bảo vệ môi trường khi triển khai nhiêu chính sách môi trường áp dụng đối với các hoạt động kinh doanh vận tải (Bảng 3).

Bảng 3 cho thấy Chính phủ Việt Nam hướng tới sự kết hợp của nhiêu giải pháp bao gồm kỹ thuật, xã hội và áp dụng công cụ kinh tế. Tuy nhiều chính sách mới được đưa ra và cần thời gian để khẳng định tính thực tiễn và hiệu quả, nền tảng và hành lang pháp lý này đã làm thay đổi nhận thức của các bên có liên quan đồng thời khuyến khích các doanh nghiệp trong ngành vận tải biển định hướng rõ ràng hơn trong việc sản xuất và kinh doanh thân thiện với môi trường. 
Bảng 3. Các quy định và chính sách có liên quan đến ngành vận tải biển Việt Nam.

\begin{tabular}{lll}
\hline Năm & Tên quy định, khung pháp lí, cam kết & Chi tiết \\
\hline 2017 & Thông tư số: 15/2017/TT-BGTVT & $\begin{array}{l}\text { Quy chuẩn kỹ thuật quốc gia về phân cấp và đóng phương } \\
\text { tiện thủy nội địa vỏ thép chở xô hóa chất nguy hiểm - Sưa } \\
\end{array}$ \\
& đổi lần 1:2016 QCVN 01:2008/BGTVT và Quy chuẩn kỹ thuật \\
& quốc gia về ngăn ngừa ô nhiễm do phương tiện thủy nội địa \\
& - Sửa đổi lần 2:2016 QCVN 17:2011/BGTVT
\end{tabular}

\begin{tabular}{ll}
\hline 2017 & Thông tư số 41/2017/TT-BGTVT \\
\hline 2017 & Thông tư số 46/2017/TT-BGTVT \\
\hline 2017 & Luật Lâm Nghiệp \\
\hline 2017 & $\begin{array}{l}\text { Chương trình quốc gia về giảm phát } \\
\text { thải KNK thông qua hạn chế mất và } \\
\text { suy thoái rừng; bảo tồn, nâng cao trữ } \\
\text { lượng các - bon và quản lý bền vững tài } \\
\text { nguyên rừng đến năm 2030 }\end{array}$
\end{tabular}

Quy định về quản lý thu gom và xử lý chất thải từ tàu thuyền trong vùng nước cảng biển

Quy định về an toàn và phòng ngừa ô nhiễm môi trường khi vận chuyển hàng nguy hiểm bằng tàu biển

Bên sử dụng dịch vụ môi trường rừng phải chi trả tiền dịch vụ môi trường rừng cho bên cung ứng dịch vụ môi trường rừng

Chương trình REDD+ nhằm hướng tới giải quyết các nguyên nhân dẫn đến phá rừng và suy thoái rừng (bao gồm rừng ngập mặn) và chuyển dịch ưu tiên sang cải thiện chất lượng rừng tự nhiên và rừng trồng, hạn chế mất rừng nhằm tối đa hóa các lợi ích xã hội, kinh tế và môi trường; khai thác giá trị dịch vụ môi trường rừng, tạo nguồn tài chính bền vững cho bảo vệ và phát triển rừng

\begin{tabular}{lll}
\hline 2018 & Thông tư số 40/2018/TT-BGTVT & $\begin{array}{l}\text { Quy định về thu thập và báo cáo tiêu thụ nhiên liệu của tàu } \\
\text { biển Việt Nam }\end{array}$ \\
\hline 2018 & Thông tư số 09/2019/TT-BGTVT & QCVN 26·2018/BGTVT Quy chuẩn kỹ thuật quốc gia về các
\end{tabular}

2018 Thông tư số 09/2019/TT-BGTVT QCVN 26:2018/BGTVT Quy chuẩn kỹ thuật quốc gia về các hệ thống ngăn ngừa ô nhiễm biển của tàu

2020 Quyết định số 2027/QĐ-BGTVT phê duyệt Đề án phát triển Cảng Xanh tại Việt Nam

Quan điểm chỉ đạo của Nhà nước: Tôn trọng quy luật tự nhiên, phù hợp với điều kiện thực tế, tránh can thiệp thô bạo vào tự nhiên; chọn mô hình thích ứng theo tự nhiên, thân thiện với môi trường và phát triển bền vững với phương châm chủ động sống chung với lũ, ngập, nước lợ, nước mặn; nghiên cứu, xây dựng các kịch bản và có giải pháp ứng phó hiệu quả với thiên tai như bão, lũ, hạn hán và xâm nhập mặn, với các tình huống bất lợi nhất do biến đổi khí hậu và phát triển thượng nguồn sông Mê Kông. Phát triển kinh tế gắn liền với phát triển xã hội, giảm nghèo, tạo việc làm, giải quyết an sinh xã hội, bảo vệ môi trường và xây dựng nông thôn mới. Khuyến khích sự tham gia của tất cả các bên liên quan, bảo đảm sự gắn kết hữu cơ trong nội vùng cũng như sự liên kết chặt chẽ với vùng kinh tế trọng điểm phía Nam và Tiểu vùng sông Mê Kông. Một trong những giải pháp được đưa ra cho việc thực hiện Đề án Cảng Xanh là bảo vệ bờ biển, bảo vệ và phát triển rừng ngập mặn

2020 Luật Bảo vệ Môi trường Các chính sách quốc gia ưu tiên xử lý ô nhiễm môi trường, phục hồi hệ sinh thái tự nhiên bị suy thoái, chú trọng bảo vệ môi trường khu dân cứ. Nhà nước nhấn mạnh sự cần thiết trong việc đa dạng hóa các nguồn vốn đầu tư cho bảo vệ môi trường

2020 Cam kết tự nguyện quốc gia và trong trường hợp có sự hỗ trợ của quốc tế sẽ nâng mức giảm phát thải lên $27 \%$ 


\subsection{Các giải pháp kinh tế và thị trường}

\subsubsection{Giải pháp kinh tế}

Đối với các doanh nghiệp kinh doanh vận tải biển, vấn đề thách thức được đặt ra khi thực hiện các giải pháp môi trường là chi phí phát sinh có thể làm ảnh hưởng tới doanh thu của họ. Tổ chức Vận tải biển Quốc tế (IMO) đã đặt tham vọng giảm ít nhất $50 \%$ lượng phát thải $\mathrm{KNK}$ của ngành vận tải biển vào năm 2050 so với năm 2008 , và giảm $40 \%$ cường độ phát thải Các-bon vào năm 2030 và $70 \%$ vào năm 2050 so với 2008 cấp. Mức độ khẩn cấp là rõ ràng, nhưng tổng chi phí khử Các-bon ước tính là 1,65 nghìn tỷ đô la vào năm 2050 (Healy và Graichen 2019).

Cụ thể hơn, Hình 3 thể hiện rõ hơn 3 loại chi phí liên quan tới các hoạt động kinh doanh vận tải biển.

Chi phí vốn và chi phí chuyến đi lần lượt chiếm $42 \%$ và $40 \%$ tổng chi phí vận chuyển đối với một hãng vận tải hàng rời cỡ 10 năm tuổi (tính theo giá năm 2005) với chi phí hoạt động chiếm thêm $14 \%$ tổng chi phí vận chuyển (Stopford 2009). Cũng theo Stopford (2009), chi phí bảo hiểm chiếm 32\% tổng chi phí hoạt động của một tàu hàng rời cỡ 10 năm tuổi, tiếp theo là chi phí thủy thủ đoàn $(31 \%)$, bảo trì và sửa chữa $(15 \%)$, mua sắm các vật dụng và vật tư tiêu hao (11\%) và chi phí chung (11\%).
Một số báo cáo đã chỉ ra rằng trong 1 thập kỷ qua ngành vận tải đã phải trải qua các giai đoạn khủng hoảng tài chính dẫn tới khó khăn trong đảm bảo lợi nhuận (Chính phủ Châu Âu 2020). Chính bởi vậy, các quốc gia đang phát triển như Ấn Độ và Brazil đêu bày tỏ lo ngại về việc phải cắt giảm phát thải $\mathrm{CO}_{2}$ đặc biệt là khi nền kinh tế và kỹ thuật của các quốc gia này còn yếu và do vậy để đảm bảo được mục tiêu giảm phát thải sẽ phải bỏ ra chi phí lớn gây thiệt hại cho hoạt động kinh doanh của họ (Fenhann 2017). Trong khi các nước đang phát triển chủ yếu dùng tàu cũ cần đâu tư cải thiện lớn về mặt công nghệ, việc tìm kiếm các giải pháp kinh tế khác như mua tàu mới không dễ dàng (Chính phủ Châu Âu 2020). Những nghiên cứu gần đây cũng cho thấy mức đâu tư cho việc xây dựng các tàu thân thiện với môi trường như Triple $\mathrm{E}$ mới của Maersk Line, có giá 185 triệu USD/ chiếc (Fenhann 2017) là rất khó khả thi cho các nước đang phát triển. Ngoài ra, khi EU đưa hoạt động vận chuyển vận tải biển vào thị trường Các-bon, nhiều tập đoàn trên toàn cầu đã phản đối vì họ sợ rằng việc bao gồm các chuyến đi đường dài trong hệ thống thương mại khí thải của EU sẽ dẫn đến tình trạng các hãng tàu tìm cách lách luật (ví dụ như để tránh phải trả tiền cho giấy phép ô nhiễm trên các chuyến đi xuyên lục địa, các chủ hàng cảnh báo họ có thể chỉ cân trốn tránh định giá Các-bon của $\mathrm{EU}$ bằng cách dừng lại ở các nước láng giềng không thuộc EU, chẳng hạn như ở Maroc, trước khi đến Tây Ban Nha, và sau đó chỉ mua giấy phép cho chặng ngắn, chặng cuối cùng của chuyến đi) để giảm chi phí vận chuyển (Defour và Afonso 2020).

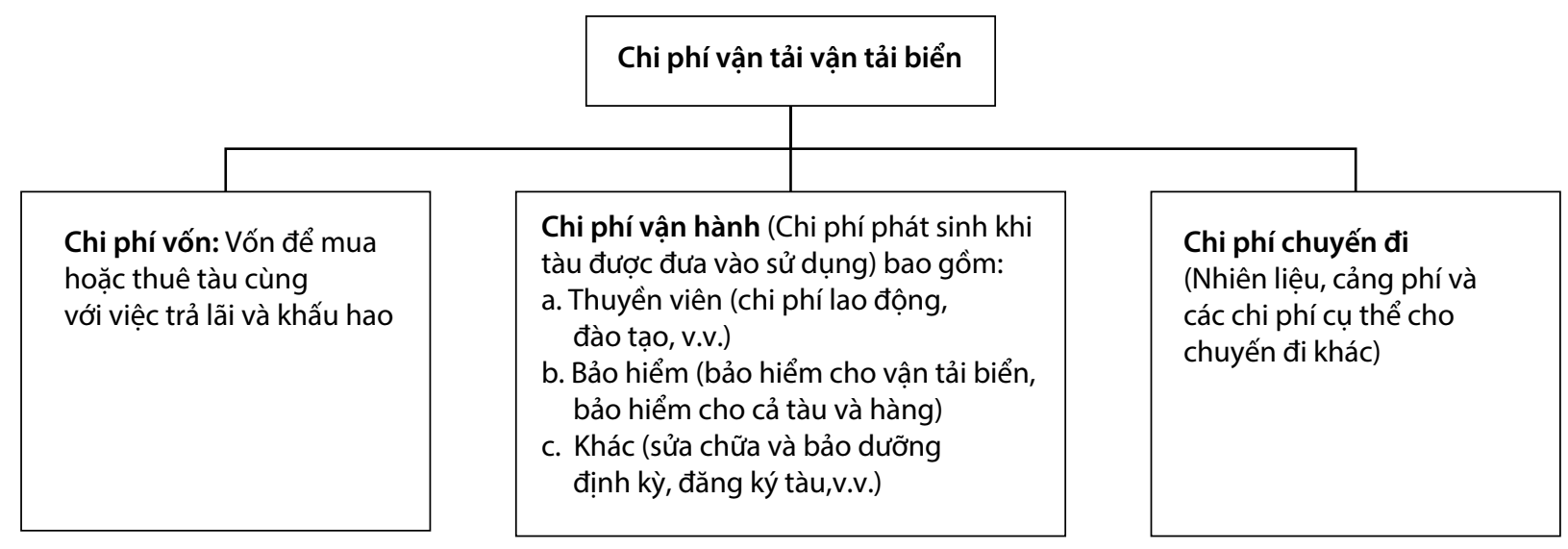

Hình 3. Chi phí liên quan tới các hoạt động vận tải biển 
Tuy nhiên, việc chọn giải pháp lách luật này sẽ chỉ giúp các doanh nghiệp tiết kiệm được 7\% (Hargreaves 2021), do các chi phí phụ tăng bao gồm nhiên liệu, phí cảng, chi phí trả cho thủy thủ đoàn, bảo hiểm, và chi phí cơ hội trong khi đó chi phí xin giấy phép ô nhiễm tối đa chỉ lên tới từ $1 \%-2 \%$ tổng chi phí vận chuyển (Hargreaves 2020, Hargreaves 2021, James 2021). Ngoài ra, dù EU sẽ bổ sung ngành vận tải biển vào thị trường Các-bon, nhưng vẫn chưa rõ chuyến đi nào sẽ được quyền mua và hưởng bảo hiểm do vậy cần xây dựng các hệ thống bảo hiểm trên phạm vi toàn câu để đảm bảo an toàn tài chính cho cả chuyến đến và chuyến đi (Hargreaves 2021).

Do ngành vận tải biển bao gồm nhiêu bên tham gia: (i) chủ tàu, chủ sở hữu và nhà đầu tư vào tàu biển; (ii) người thuê tàu bao gồm các công ty vận chuyển thuê và vận hành một con tàu để vận chuyển hàng hóa và (iii) các nhà quản lý kỹ thuật, các hãng tàu vận chuyển hàng hóa có nguồn gốc ở nhiêu nơi, tới và dừng tại nhiều quốc gia, kết nối với các mạng lưới công ty với quy mô khác nhau (Selin and Cowling 2018), một vấn đề đặt ra là ai sẽ là người chịu chi phí phát sinh khi thực hiện các giải pháp môi trường bởi ai trong chuỗi cung ứng dịch vụ này cũng muốn tiết kiệm chi phí bỏ ra (Fenhann 2017).

Trong khi nhiều doanh nghiệp đang lo ngại về các chi phí phát sinh, nhiều tập đoàn tài chính chủ yếu là các ngân hàng thương mại và các nhà quản lý tài sản với hơn 50 tỷ đô la Mỹ lại đặt ưu tiên đâu tư vào vận tải biển, du lịch biển và ven biển, và năng lượng tái tạo trên biển bởi họ tin rằng đây là mô hình đâu tư bên vững, đặc biệt trong bối cảnh giảm phát thải KNK (World Ocean 2021). Năm 2019, các tổ chức vận tải biển quốc tế, bao gồm Phòng Vận tải biển Quốc tế cũng đã đề xuất tạo quỹ 5 tỷ đô la để hỗ trợ nghiên cứu và công nghệ cần thiết để cắt giảm phát thải KNK (Saul 2019).

\subsubsection{Giải pháp thị trường}

Các Quy định của Châu Âu và Kế hoạch IMO đêu nhấn mạnh tầm quan trọng của các biện pháp và công cụ chính sách dựa vào thị trường (Curtis 2012, EC 2016). Như chúng tôi đã trình bày ở phần trên, thế giới và khối EU, Mỹ đều xây dựng thị trường Các-bon và thị trường giảm phát thải. Việc quy định bảo vệ môi trường ngày càng siết chặt cùng với sự ra đời của thị trường Các-bon quốc tế và nội địa sẽ thúc đẩy các doanh nghiệp và quốc gia thực hiện và trao đổi kết quả giảm phát thải của mình. Thị trường Các-bon và các chính sách thương mại phát thải cũng đề cập rõ tới sự tham gia bắt buộc của các lĩnh vực và ngành kinh tế, trong đó có vận tải biển (EC 2016).

\subsection{Các giải pháp kỹ thuật}

Trước thực trạng ô nhiễm môi trường do ngành vận tải biển gây ra, nhiều quy định và hướng dẫn kỹ thuật trong và ngoài nước đã được đưa ra để hạn chế và giảm thiểu tác động môi trường (Bảng 2 và Bảng 3 ). Các giải pháp này tập trung vào đổi mới công nghệ và thay thế nhiên liệu sạch. Nhờ có các quy định này, khối lượng vận chuyển đã tăng 101\% trong khi lượng khí thải chỉ tăng 40\% so với cùng khung thời gian và đến năm 2008 , hiệu suất Các-bon trên mỗi khoảng cách trọng lượng của một số tàu đã cải thiện $75 \%$ (Shell và Deloitte 2020). Nhiêu tập đoàn lớn đã đâu tư vào chuyển đổi công nghệ và thay thế nhiên liệu gây ra nhiều ô nhiễm sang các loại nhiên liệu thân thiện với môi trường. Tuy nhiên, số lượng các doanh nghiệp và hãng vận tải biển sử dụng nhiên liệu sạch thay thế trong nhiều năm qua vẫn còn rất hạn chế (CC 2020, Ovcina 2020). Ngoài ra, mặc dù các chủ tàu lúc đâu quan tâm tới tính hiệu quả của sử dụng năng lượng vì nhiên liệu chiếm khoảng 25\% chi phí cơ bản của vận tải biển, việc giá dâu giảm mạnh vào năm 2014 đã làm giảm sự quan tâm đầu tư vào hiệu quả năng lượng do lợi nhuận giảm (Fenhann 2017).

Hơn nữa, mặc dù có nhiều giải pháp kỹ thuật được đưa ra, các giải pháp này khó có thể giúp ngành vận tải biển đạt được mục tiêu giảm phát thải tới $40 \%$ vào năm 2030 . Chính điều này cũng tạo ra nhiều lo ngại và áp lực cho cộng đông quốc tế về việc ngành vận tải biển không thể đạt mục tiêu của Thỏa thuận Paris.

\section{Các giải pháp kỹ thuật giảm nhiên liệu không} thực sự hiệu quả. Mặc dù ngành vận tải biển khẳng định rằng họ luôn cố gắng nâng cao hiệu quả hoạt động đối với môi trường, nhiều nghiên cứu (Bannon 2016) lại chứng minh được rằng, trong thực tế các tàu được sản xuất trong những năm gần đây lại sử dụng nhiều hơn (khoảng 10\%) nhiên liệu so với các tàu được sản xuất ở thời điểm trước (Abbasov 2020). Điều này cũng lí giải áp lực và sự vận động hành lang cho việc ngày càng siết chặt chính sách quản lý với ngành vận tải biển. 
Chỉ số EEDI không thực sự hiệu quả để đạt được mục tiêu giảm phát thải. IMO đã thừa nhận rằng, chỉ số EEDI không phải là một chỉ số đánh giá hiệu quả bởi nó không thực sự thúc đẩy các doanh nghiệp cải thiện kỹ thuật hoặc sử dụng nhiên liệu hiệu quả hơn (Bannon 2016). Cũng bởi các chỉ số đánh giá này quá dễ dãi, khoảng $70 \%$ các tàu container mới đóng, tạo phát thải khoảng $1 / 4$ lượng khí thải $\mathrm{CO}_{2}$ của tàu bè trên toàn cầu cho tới nay đã đạt được yêu cầu đề ra cho tới năm 2025 (Bannon 2016). Điều này khuyến khích một triết lý về sự thận trọng. Trong mọi trường hợp, IMO tập trung vào phát thải $\mathrm{CO}_{2}$ và đã đồng ý quy định mới của EEDI. Sáng kiến này sẽ mất một thời gian và chưa thực sự sắc nét, nhửng ít nhất quá trình thực hiện nó đã bắt đâu. IMO cũng đã đồng ý Chỉ số Thiết kế Hiệu quả Năng lượng (EEDI), đối với các tàu trên 400 tấn (GT) lưu thông quốc tế, hoặc xấp xỉ 95\% tổng số tàu. Vận chuyển nội địa bị loại trừ khỏi EEDI và thay vào đó sẽ nằm trong tài khoản phát thải $\mathrm{CO}_{2}$ cho mỗi quốc gia. Không phải tất cả các tàu du lịch đều chưa được đưa vào chế độ EEDI. EEDI có các yêu câu và giai đoạn sau: Giai đoạn 0 của EEDI có hiệu lực vào năm 2013 và cung cấp cho tất cả các loại tàu diesel và nhiên liệu kép mới được đóng sau ngày 1 tháng 1 năm 2013 một công thức tính hiệu quả. Giai đoạn này được ngành công nghiệp hoàn thành tương đối dễ dàng. Từ năm 2015, giai đoạn 1 yêu câu giảm $10 \%$ lượng $\mathrm{CO}_{2}$ so với năm 2013 cũng đã được ngành thực hiện dễ dàng. Giai đoạn 2 sẽ có hiệu lực sau ngày 1 tháng 1 năm 2020, nhưng điêu này đang gặp phải sự cản trở trong ngành vận tải biển. Giai đoạn 3 nghiêm ngặt hơn, yêu câu giảm $30 \%$ lượng khí thải $\mathrm{CO}_{2}$, sẽ có hiệu lực vào năm 2025 (Fenhann 2017).

\section{Giải pháp đốt hơi chậm và giảm tốc độ vận} chuyển của tàu cũng chưa đạt được mục tiêu tối ưu để giảm phát thải. Với phương thức đốt hơi chậm, hệ thống máy móc vận hành của tàu sẽ không chạy ở công suất tối đa, do vậy có thể tiết kiệm được nhiên liệu đốt và giảm phát thải khí ô nhiễm. Khi giảm tốc độ của tàu xuống $10 \%$ thì sẽ giảm phát thải của tàu lên tới $27 \%$. Tốc độ tàu giảm $25 \%$ dẫn đến giảm tiêu thụ nhiên liệu máy chính khoảng 58\% một năm. Tốc độ tàu thấp hơn cũng sẽ làm giảm tác động tiêu cực đối với loài động vật biển (Curtis 2012). Tuy nhiên, điêu này cũng đồng nghĩa khả năng cung ứng của thị trường giảm khi cần có nhiều tàu hơn để chuyển cùng một lượng hàng so với trước đây. Do vậy nếu tính cả tổng lượng phát thải từ các tòa nhà và vận hành tàu mới thì trong thực tế, giải pháp này chỉ giảm được $19 \%$ lượng phát thải (Curtis 2012). Hâu hết tốc độ tàu không thay đổi trong giai đoạn 2013 - 2015. Tuy nhiên, các tàu chở dâu lớn nhất (>200.000 DWT) và tàu container lớn nhất (> 14.500 TEU) dường như đã tăng tốc độ lên khoảng $4 \%$ và $11 \%$ tương ứng giữa năm 2013 và 2015 (Reynolds 2019). Ngoài ra, trong thực tế các hãng tàu giảm nhiên liệu tiêu thụ bằng cách giảm tốc độ di chuyển của tàu là để giảm chi phí trong bối cảnh khủng hoảng kinh tế hiện nay chứ không phải vì lấy mục tiêu môi trường làm hàng đầu. Tuy nhiên, dù không thể đạt được mục tiêu tối đa như kỳ vọng, giảm vận tốc di chuyển của tàu bằng cách đốt hơi thấp vẫn có thể đóng góp vào mục tiêu giảm phát thải của ngành vận tải biển và do vậy vẫn được coi như một chính sách quan trọng trong chiến lược thích ứng và giảm thiểu biến đổi khí . Đặc biệt khi giải pháp chính sách này có thể dễ dàng thực hiện cả vê pháp lý và kỹ thuật khi áp dụng Automatic Identification System (AIS) (Shipmap 2012), một hệ thống bắt buộc đã được áp dụng cho các tàu lớn đặc biệt khi nó cung cấp các thông tin về vị trí tàu đi qua, tốc độ và hướng đi các tàu không thể trốn hoặc đưa các thông tin giả về hoạt động của mình (Faber và cộng sự 2020). Ngoài ra, EEDI cũng được tính toán cho mỗi con tàu được đóng mới bằng cách sử dụng một công thức phức tạp bao gồm một số yếu tố và hệ số để thể hiện lợi ích khí hậu đối với xã hội, trọng lượng chết của con tàu, lượng khí thải và tốc độ cũng như các thông số kỹ thuật khác (Fenhann 2017).

\section{Khí ga tự nhiên hoá lỏng (Liquid natural gas - LNG) - giải pháp hay vấn đề phải giải quyết} mới? LNG hiện cũng đang trở thành một giải pháp được nhiều bên xem xét khi nó có thể giảm khí thải $\mathrm{SO}_{\mathrm{x}}$ tới $100 \%$ và khí thải $\mathrm{NO}_{\mathrm{x}}$ tới $90 \%$. Tuy nhiên, việc sử dụng Khí ga tự nhiên hóa lỏng (LNG) chỉ chiếm 3\% tổng lượng nhiên liệu tiêu thụ (Ủy ban Châu Âu 2020). Nhiều nghiên cứu đã chỉ ra rằng trong thực tế, trường hợp tốt nhất thì LNG cũng chỉ làm giảm thêm tối đa $10 \%$ lượng khí thải nhà kính so với việc sử dụng nguyên liệu xăng dầu thông thường và sẽ giảm dần với lượng thương mại hàng hóa tăng nhanh. Nếu rò rỉ khí Methane tăng cao, một số nghiên cứu còn chỉ ra rằng sử dụng LNG thậm chí còn làm tăng lượng phát thải KNK so với sử dụng nhiên liệu thông thường (Bannon 2016). Ngoài ra, việc sử dụng LNG thay vì dâu nhiên liệu nặng (HFO) và dâuu khí biển ( $\mathrm{MGO}$ ) được cho rằng sẽ đem lại lợi ích cho sức khỏe con người, LNG 
không phải là công nghệ và giải pháp kỹ thuật duy nhất để giảm phát thải (Abbasov 2019)._Dâu khí biển sạch hơn với hàm lượng lưu huỳnh 10 ppm (tương tự như nhiên liệu đường bộ), cùng với hệ thống khử xúc tác chọn lọc (SCR) và bộ lọc hạt động cơ diesel (DPF) có thể đem lại lợi ích tương tự như LNG. Đông thời, không giống như khí tự nhiên, các công nghệ này sẽ không yêu câu phải thay đổi tàu hoặc đâu tư đắt đỏ trong việc xây dựng cơ sở hạ tầng tiếp nhiên liệu như LNG. Như vậy nếu xét về mặt chi phí và lợi ích thì việc làm sạch nhiên liệu hiện sẽ rẻ và hợp lý hơn (Abbasov 2019). Vể lý thuyết, hàm lượng các-bon thấp hơn của LNG làm giảm lượng khí thải $\mathrm{CO}_{2}$, nhưng điêu này chưa tính đến việc khi sử dụng LNG, sự trượt và rò rỉ khí mê-tan liên quan trong quá trình khai thác, vận chuyển, hầm lò và đặc biệt là sử dụng LNG trên tàu. Khí mêtan hóa thạch $\left(\mathrm{CH}_{4}\right)$ có nồng độ $\mathrm{KNK}$ cao gấp 30 lân (khi tính trung bình trong hơn 100 năm) so với $\mathrm{CO}_{2}$. Việc sử dụng LNG có nguy cơ thực sự làm tăng tác động đến khí hậu của vận chuyển thay vì giảm nó (Abbasov 2019). Ngoài việc nguôn cung cho LNG chưa đáp ứng đủ nhu câu, chi phí đầu tư do thiếu cơ sở hạ tâng cũng rất cao (Fenhann 2017).

Năng lượng tái tạo, năng lượng sinh học. Việc phát triển các nhiên liệu thay thế và các hệ thống động cơ sẽ phải được đẩy nhanh nếu đội tàu toàn cầu giảm đáng kể lượng khí thải $\mathrm{CO}_{2}$ và các bước đầu tiên để làm như vậy đã được thực hiện. Tuy nhiên, việc giới thiệu các loại nhiên liệu mới thay thế trong linh vực này rất phức tạp và tốn thời gian, và xu hướng là các tàu container khổng lô có chiều dài lên đến 400 mét và mức tiêu thụ nhiên liệu hàng ngày là 80.000 lít được sử dụng cho vận tải hàng hóa bằng đường biển (Fenhann 2017). Ngoài ra, nhiên liệu có nguồn gốc từ sinh khối có thể được sử dụng cho giao thông vận tải biển, nhưng sẽ cần những diện tích đất rộng lớn để trồng trọt với số lượng cây trông cần thiết trong khi diện tích cho các cây trồng mới ngày càng bị thu hẹp trên toàn câu.

\subsection{Các giải pháp xã hội}

Người tiêu dùng ngày càng quan tâm nhiều hơn đến trách nhiệm xã hội của doanh nghiệp. Lĩnh vực vận tải biển cũng không loại trừ. Các doanh nghiệp vận tải biển ngày càng chú ý hơn đến những tác động mà vận tải biển gây ra với môi trường nên có thể đầu tư vào những đội tàu tiết kiệm nhiên liệu. Họ hoạt động trong khuôn khổ các công ước và điều luật quốc tế dưới sự giám sát của Tổ chức Hàng hải Quốc tế (IMO) vể bảo vệ môi trường, đảm bảo an toàn cho thuyền viên, quyền lợi của các chuyên gia trong ngành vận tải biển (Hiteshk 2019).

Dù CSR là một khái niệm còn khá mới mẻ trong ngành, vai trò của CSR ngày càng quan trọng. CSR có thể giúp cho ngành vận tải biển tạo dựng quyền của những con tàu thân thiện môi trường; phúc lợi của thuyền viên và gia đình họ về an toàn, an ninh, sức khỏe và truyền thông; xây dựng sự thống nhất trong đa dạng; truyền thông có đạo đức về các chính sách của công ty cho các bên liên quan; tạo quan hệ tốt giữa công ty và người lao động; xây dựng thương hiệu vận tải biển uy tín (Maritime Transport 2016).

Cơ chế thị trường với yêu cầu ngày càng khắt khe của khách hàng cũng là động lực thúc đẩy ngành vận tải biển hướng tới bảo vệ môi trường để giữ vững được thị phẩn (Shell và Deloitte 2020). Ví dụ, Maersk Line đã ký thỏa thuận và kế hoạch giảm lượng $\mathrm{CO}_{2}$ của họ và các công ty như $\mathrm{BMW}$, AkzoNobel và Huawei như một minh chứng với khách hàng về cam kết phát triển xanh của mình (Fenhann 2017). Tương tự như vậy, Unilever cũng đã công bố trên toàn cầu rằng họ sẽ dán nhãn trên tất cả các sản phẩm của mình để công bố cho khách hàng biết biết lượng $\mathrm{CO}_{2}$ đã được thải ra trong quá trình sản xuất và vận chuyển của công ty mình (Unilever 2021). Nhiều cảng trên thế giới như cảng Port Everglades tại Florida đầu tư vào rừng ngập mặn như cam kết bảo vệ môi trường bên vững của mình (Kennedy 2016). Các doanh nghiệp vận tải như Tokio Marine Holdings, Inc với công ty con của tập đoàn Tokio Marine và Nichido Fire Insurance Co., Ltd. cũng mở rộng diện tích rừng ngập mặn như một biện pháp phát triển kinh tế các-bon thấp (Tokio Marine Holdings 2020). 


\section{Vai trò của rừng ngập mặn trong việc hỗ trợ ngành vận tải biển và vận tải biển giảm phát thải, bảo vệ môi trường và phát triển bền vững}

Các hệ sinh thái rừng ngập mặn đóng vai trò quan trọng trong việc bảo vệ môi trường của TP.HCM và các vùng lân cận. Ví dụ rừng ngập mặn ở Cân Giờ không chỉ cung cấp một lượng lớn oxy, hấp thụ và lưu trữ $\mathrm{CO}_{2}(\sim 80$ tấn / ha / năm), mà còn góp phần giảm KNK. RNM Cần Giờ cũng là môi trường sống cho sinh vật biển các loài thủy sinh giá trị, và là môi trường sống của cư dân địa phương và ngư dân. Rừng ngập mặn cung cấp sự bảo vệ khỏi bão và xói mòn ven biển. Đây cũng là một hệ sinh thái được quan tâm đặc biệt đối với phát triển du lịch sinh thái, giáo dục môi trường và các khóa học ngoại khóa cho học sinh thành phố và các khu vực lân cận (Shingeyuki và cộng sự 2014).

Rừng ngập mặn cũng đóng góp đáng kể vào sự phát triển kinh tế xã hội của Việt Nam, đặc biệt là của các cộng đông ven biển. Những đóng góp đó bao gồm việc cung cấp củi, than củi, cột điện, vật liệu xây dựng, bột giấy,... Bên cạnh giá trị kinh tế trực tiếp vễ gỗ và chất đốt, rừng ngập mặn còn có vai trò một vai trò quan trọng trong sản xuất bền vững cá, tôm, sò huyết, cua, v.v. và rất quan trọng

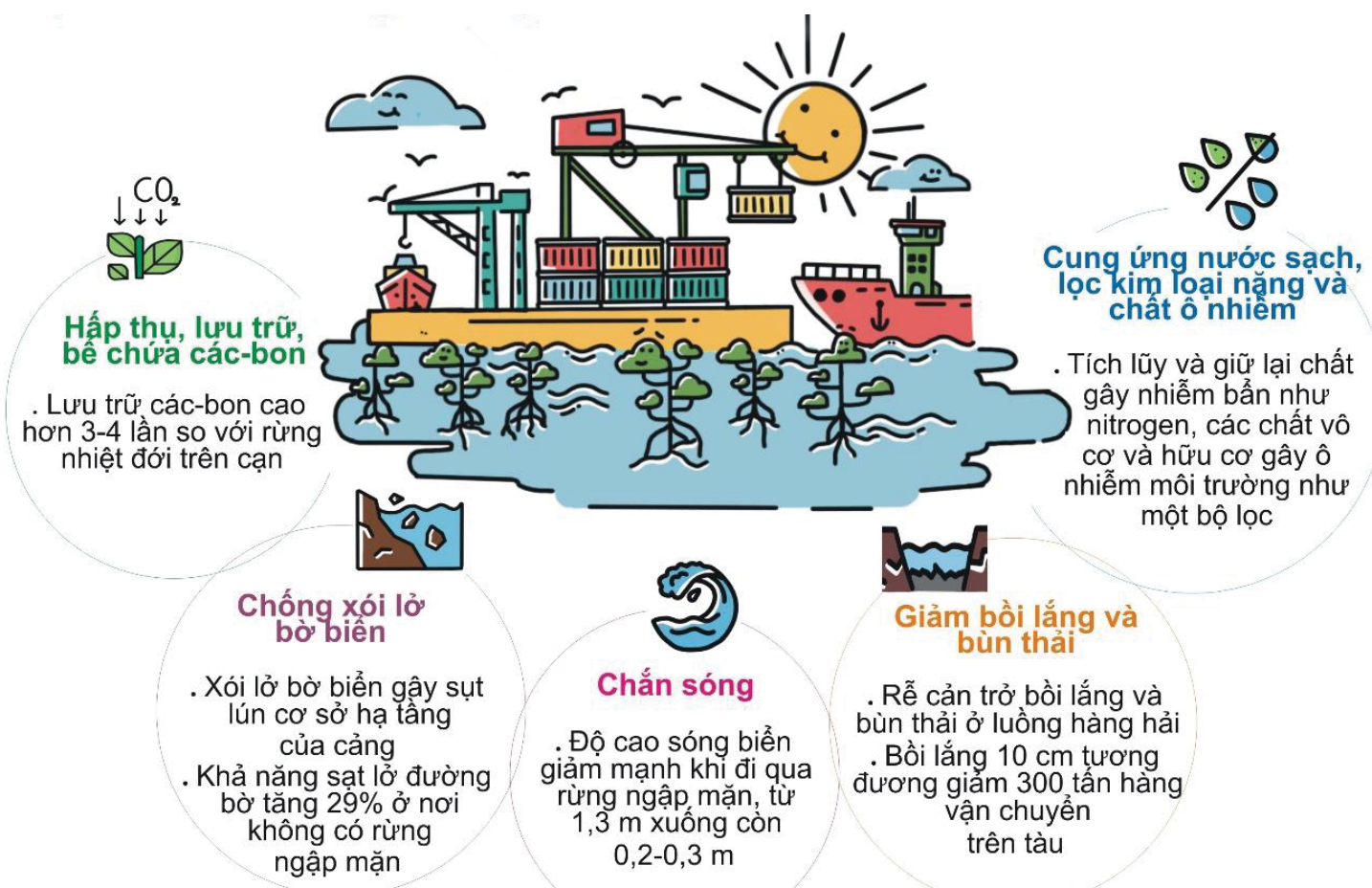

Hình 4. Vai trò của rừng ngập mặn đối với ngành vận tải biển

Nguồn: Hoài Đan (2021) 
Bảng 4. Vai trò và tiềm năng của rừng ngập mặn trong việc giải quyết các tác động tiêu của của ngành vận tải biển đối với môi trường

\begin{tabular}{|c|c|}
\hline Vấn đề & Vai trò của rừng ngập mặn \\
\hline $\begin{array}{l}\text { Ô nhiễm không khí/ } \\
\text { phát thải KNK }\end{array}$ & $\begin{array}{l}\text { Rừng ngập mặn là một trong những bể chứa Các-bon quan trọng nhất trên hành tinh. } \\
\text { Rừng ngập măan có khả năng cô lập Các-bon hiệu quả hơn } 10 \text { lần so với rừng mưa nhiệt } \\
\text { đới và có khả năng hấp thụ Các-bon cao từ 3-5 lần so với rừng trên cạn }\end{array}$ \\
\hline Ô nhiễm nước & $\begin{array}{l}\text { Rừng ngập mặn có khả năng tích lũy kim loại nặng và do đó có khả năng làm sạch } \\
\text { nước thải }\end{array}$ \\
\hline Ô nhiễm tiếng ồn & $\begin{array}{l}\text { Rừng ngập mặn có khả năng làm giảm tiếng ồn do các hoạt động vận tải biển gây ra. Khả } \\
\text { năng làm giảm tiếng ồn tùy thuộc vào dải dày của rừng ngập mặn và mật độ cây trồng }\end{array}$ \\
\hline $\begin{array}{l}\text { Xói lở và sụt lún bờ } \\
\text { biển }\end{array}$ & $\begin{array}{l}\text { Bảo tồn và trồng mới rừng ngập mặn luôn được coi là giải pháp ưu tiên mà nhà nước và } \\
\text { các nhà thiết kế dự án đưa ra để giải quyết và phòng tránh xói lở và sụt lún bờ biển. }\end{array}$ \\
\hline $\begin{array}{l}\text { Ảnh hưởng sức khỏe } \\
\text { con người }\end{array}$ & $\begin{array}{l}\text { Việc rừng ngập măan có khả năng hấp thụ khí CO2 sẽ giúp tạo lá phổi xanh và không khí } \\
\text { trong lành, từ đó giảm các nguy cơ rủi ro bệnh tật cho con người, đặc biệt là bệnh hô hấp } \\
\text { và tim mạch. Ngoài ra, tắm rừng trong rừng ngập mặn còn được coi là một liệu pháp chữa } \\
\text { bệnh quan trọng đang được áp dụng tại nhiều quốc gia, ví dụ Nhật Bản }\end{array}$ \\
\hline
\end{tabular}

Nguồn: Tam và Wong (1994); Kaye (2019); Adame và cộng sự (2020); Alongi (2020); Phạm và cộng sự (2019); Phạm và cộng sự (2020)

đối với lâu dài sự ổn định của nghề cá ven biển. Do sự lưu thông chất dinh dưỡng mạnh mẽ trong rừng ngập mặn, nó cung cấp một nguồn thức ăn rất phong phú cho nhiêuu loài động vật biển và cung cấp điều kiện lý tưởng để sinh sản nuôi dưỡng các loài thủy hải sản. Nhiều nghiên cứu cũng chỉ ra mối tương quan tích cực đáng kể giữa diện tích rừng ngập mặn và đánh bắt xa bờ đặc biệt là đối với tôm (Vien và cộng sự 1993).

Nhiều nghiên cứu đã chứng minh được vai trò của rừng ngập mặn trong việc giải quyết các vấn để môi trường và xã hội do ngành vận tải biển tạo trong Hình 4 và Bảng 4.
Để có thể duy trì và mở rộng diện tích rừng ngập mặn từ đó tăng cường khả năng giảm thiểu và thích ứng với biến đổi khí hậu đồng thời hỗ trợ ngành vận tải biển thực hiện tốt hơn cam kết bảo vệ môi trường của mình, cần có nhiều chính sách tạo ra nguôn tài chính bền vững như cơ chế chi trả dịch vụ môi trường rừng. Định hướng xây dựng cơ chế chi trả dịch vụ môi trường rừng ngập mặn không chỉ phù hợp với xu thế thế giới trong việc áp dụng công cụ tài chính (e.g. thị trường Các-bon, thương mại phát thải) mà còn thúc đẩy sự tham gia của toàn xã hội trong công tác bảo vệ rừng. Cần có nhiêu nghiên cứu nâng cao nhận thức của các bên về vai trò và tiềm năng của rừng ngập mặn cũng như xây dựng cơ chế huy động và quản lí nguồn tài chính hiệu quả cho công tác bảo tồn và phát triển rừng ngập mặn. 


\section{Kết luận}

Là ngành kinh tế mũi nhọn của toàn câu và Việt Nam nhửng ngành vận tải biển cũng đối mặt với nhiêu thách thức trong việc vừa phát triển kinh tế vừa thực hiện các cam kết bảo vệ môi trường. Nhiêu giải pháp chính sách, kỹ thuật, tài chính và sinh thái đã được đưa ra để hỗ trợ ngành vận tải biển nhằm hướng tới những mục tiêu phát triển toàn diện này. Sự kết hợp đông bộ giữa các biện pháp này không những sẽ giúp ngành vận tải biển đạt được mục tiêu phát triển bển vững nhanh hơn mà còn giảm chi phí cho công tác bảo vệ môi trường. Rừng ngập mặn, với vai trò quan trọng trong cuộc chiến biến đổi khí hậu có thể hỗ trợ ngành vận tải biển trong việc giải quyết một số vấn đề ô nhiễm môi trường và đổi lại, với sự đóng góp của ngành vận tải vào việc tạo ra nguôn tài chính bền vững cho trông mới và bảo tồn rừng ngập mặn, hệ sinh thái và chỉ số môi trường xanh của Việt Nam có thể được mở rộng và gia tăng. Tuy nhiên, cần có nhiều nghiên cứu về cơ sở khoa học và cơ sở pháp lí cho việc thực hiện cơ chế chi trả dịch vụ môi trường rừng ngập mặn trong tương lai. 


\section{Tài liệu tham khảo}

Abbasov F. 2019. LNG remains a deadend for deCác-bonising maritime transport. Transport và Environment. https://www. transportenvironment.org/newsroom/blog/ lng-remains-deadend-deCác-bonisingmaritime-transport

Abasov F. 2020. Shipping and Climate change. Transport và Environment. https://www. transportenvironment.org/what-we-do/ shipping-and-environment/shipping-andclimate-change

Adame MF, Connolly RM, Turschwell MP, Lovelock CE, Fatoyinbo L, Lagomasino D, Goldberg LA, Holdorf J, Friess DA, Sasmito SD, Sanderman J, Mievers M, Bluelow C, Kaufman BJ, Bryan-Brown D, Brown CJ. 2020. Future Các-bon emissions from global mangrove forest loss. Global Change Biology. doi: https://doi. org/10.1101/2020.08.27.271189

Alongi D. 2020. Global Significance of Mangrove Blue Các-bon in Climate Change Mitigation (Version 1). Preprints: Sci 2020, 2, 67. DOI: 10.3390/sci2030067. https://www.preprints. org/manuscript/202011.0139/v1

Anthony EJ, Brunier G, Beset M, Goichot M, Dusouillez P, and Nguyen VP. 2015. Liên hệ giũa xói lở nhanh ở đông bằng sông Củu Long và các hoạt động của con người. Scientific Reports. http://d2ouvy59p0dg6k.cloudfront. net/downloads/bao_cao_khoa_hc_v_ xoi_l_b_song_cu_long.pdf

Bannon E. 2016. Natural gas vehicles an expensive, ineffective way to cut car and truck emissions - not a 'bridge fuel'. Transport và Environment. https://www. transportenvironment.org/press/naturalgas-vehicles-expensive-ineffective-way-cutcar-and-truck-emissions- $\% \mathrm{E} 2 \% 80 \% 93$-not$\%$ E2\%80\%98bridge-fuel\%E2\%80\%99
Bannon E. 2016. Study of historical trends in ship design efficiency 2016. Transport và Environment. https://www. transportenvironment.org/publications/ study-historical-trends-ship-designefficiency-2016

Beyer J, Trannum HC, Bakke T, Hodson PV and Collier TK. 2016. Environmental effects of the Deepwater Horizon oil spill: A review. Marine Pollution Bulletin 110(1): 28-51.

Bowers C. 2020a. Shipping body's climate plan 'ignores Paris Agreement'. Transport và Environment. https:// www.transportenvironment.org/news/ shipping-body\%E2\%80\%99s-climateplan-\%E2\%80\%98ignores-parisagreement $\% \mathrm{E} 2 \% 80 \% 99$

Bowers C. 2020b. Case for shipping in Các-bon market now 'indisputable'. Transport và environmet. https:// www.transportenvironment.org/news/ case-shipping-Các-bon-market-now\%E2\%80\%98indisputable\%E2\%80\%99

Bowers C. 2021a. Shipping must embrace cleaner future or become 'uninvestable'. Transport và Environment. https://www. transportenvironment.org/news/shippingmust-embrace-cleaner-future-or-becomeuninvestable

Bowers C. 2021b. World's first 'Các-bon neutral' ship will rely on dead-end fuel. Transport và Environment. https:// www.transportenvironment.org/news/ world\%E2\%80\%99s-first-\%E2\%80\%98Cácbon-neutral\%E2\%80\%99-ship-will-relydead-end-fuel

Bowers C. 2021c. UK moves ahead of EU in closing loophole on airline and ship pollution. Transport và Environment. https://www. transportenvironment.org/news/uk-movesahead-eu-closing-loophole-airline-and-shippollution 
[CC] Clean Cargo. 2020. 2019 Global Container Shipping Trade Lane Emissions Factors. https://static1.squarespace.com/ static/5b3f37f489c17230345b5f15/t/5f4610 9c14efc67813f2bca8/1598427336870/BSRClean-Cargo-Emissions-Report-2020.pdf

Bộ Tài nguyên và Môi trường. 2020. Đóng góp của ngành kinh tế biên. Cổng thông tin điện tử. https://monre.gov.vn/Pages/dong-gopcua-cac-nganh-kinh-te-bien.aspx

Curtis D. 2012. Smarter steaming ahead. Transport và Environment. https://www. transportenvironment.org/publications/ smarter-steaming-ahead

Curtis D. 2012. Regulated Slow Steaming in Maritime Transport: An Assessment of Options, Costs and Benefits. Transport và Environment. https://www. transportenvironment.org/publications/ regulated-slow-steaming-maritimetransport-assessment-options-costs-andbenefits

Defour S and Afonso F. 2020. All aboard! Too expensive for ships to evade EU Các-bon market. Transport và Environment. https:// www.transportenvironment.org/sites/te/files/ publications/ETS_shipping_study.pdf

Europe Oceana. 2020. Shipping Pollution. Europe Oceana. https://europe.oceana.org/en/ shipping-pollution-1

[EC] European Commission. 2013. Maritime transport: first step to reduce emissions. Brussels: European Commission. https:// ec.europa.eu/commission/presscorner/detail/ en/IP_13_622

[EC] European Commission. 2016. Reducing emissions from the shipping sector. Brussels: European Commission. https://ec.europa.eu/ clima/policies/transport/shipping_en

[EC] European Commission. 2020. Report from the commission: 2019 Annual Report on $\mathrm{CO}_{2}$ Emissions from Maritime Transport (SWD(2020) 82 final). Brussels: European Commission. https://ec.europa.eu/clima/ sites/default/files/transport/shipping/ docs/c_2020_3184_en.pdf

[EU] European Union. 2016. Commission implementing regulation (EU) 2016/1928 of 4 November 2016 on determination of cargo carried for categories of ships other than passenger, ro-ro and container ships pursuant to Regulation (EU) 2015/757 of the European Parliament and of the Council on the monitoring, reporting and verification of
Các-bon dioxide emissions from maritime transport. The European Commission. https://eur-lex.europa.eu/legal-content/ EN/TXT/?uri=uriserv:OJ.L_.2016.299.01. 0022.01.ENG

Faber J, Hanayama S, Zhang S, Pereda P, Comer $B$, Hauerhof E, van der Loeff WS, Smith T, Zhang Y, Kosaka H, Adachi M, Bonello JM, Galbraith C, Gong Z, Hirata K, Hummels D, Kleijn A, Lee DS, Liu Y, Lucchesi A, Mao X, Muraoka E, Osipova L, Qian H, Rutherford D, de la Fuente SS, Yuan H, Perico CV, Wu L, Sun D, Yoo DH and Xing H. 2021. Fourth IMO GHG Study 2020: Executive Summary. International Maritime Organization. https://wwwcdn.imo.org/localresources/ en/OurWork/Environment/Documents/ Fourth\%20IMO\%20GHG\%20Study\%20 2020\%20Executive-Summary.pdf

Fenhann J. V. 2017. $\mathrm{CO}_{2}$ Emissions from International Shipping. UNEP DTU Partnership Working Paper Series 2017 Vol. 4

Frese F. 2019. Shipping Emissions and 6 Strategies to Avoid Maritime Pollution. Xchange. https://container-xchange.com/blog/ shipping-emissions/

Kaye L. 2019. Why Apple is Investing in Colombia's Mangroves. Energy và Environment. https://www.triplepundit.com/ story/2019/why-apple-investing-colombiasmangroves/83271/

Fenhann J. V. 2017. $\mathrm{CO}_{2}$ Emissions from International Shipping. UNEP DTU Partnership Working Paper 2017, Vol. 4

Goodwin AP. 2016. The economic value of shipping and maritime activity in Europe. UK: Oxford Economics. https://www.oecd.org/ sti/ind/Session\%201_c\%20-\%20Andrew\%20 Goodwin\%20-\%20Presentation\%20for\%20 Website.pdf

Government Europa. 2020. Cleaning up the shipping industry. Fuelsave. https://fuelsaveglobal.com/cleaning-up-the-shippingindustry/

Hargreaves S. 2021. EU 'shouldn't let shippers off the hook' with Các-bon pricing. Transport và Environment. https://www. transportenvironment.org/news/eushouldn\%E2\%80\%99t-let-shippers-hookCác-bon-pricing

Healy S and Graichen J. 2019. Impact of slow steaming for different types of ships carrying bulk cargo. Oko Institute. https://www. 
transportenvironment.org/sites/te/files/ Impact $\% 20$ of $\% 20$ slow $\% 20$ steaming $\% 20$ for\%20different\%20types\%20of\%20ships $\% 20$ carrying\%20bulk\%20cargo.pdf

Helms J. 2013. World's 15 Biggest Ships Create More Pollution Than All The Cars In The World. Industry Tap. https://www. industrytap.com/worlds-15-biggest-shipscreate-more-pollution-than-all-the-cars-inthe-world/8182

Hiteshk. 2019. Integrating Corporate Social Responsibility and Maritime Industry. Marine Insight. https://www.marineinsight.com/ know-more/integrating-corporate-socialresponsibility-and-maritime-industry/

International Chamber of Shipping. 2019. Shipping and world trade: driving prosperity. https://www.ics-shipping.org/shippingfact/shipping-and-world-trade-drivingprosperity/

IPCC. 2018. Summary for Policymakers. In: Global Warming of $1.5^{\circ} \mathrm{C}$. An IPCC Special Report on the impacts of global warming of $1.5^{\circ} \mathrm{C}$ above pre-industrial levels and related global greenhouse gas emission pathways, in the context of strengthening the global response to the threat of climate change, sustainable development, and efforts to eradicate poverty. Geneva, Switzerland: World Meteorological Organization.

James G. 2021. Shipping Faces New Turmoil in European Emissions Trading Plan. Canadianeconomist. https:// canadianeconomist.com/shipping-facesnew-turmoil-in-european-emissionstrading-plan/

Kennedy E. 2016. Environmental Program Allows for Cargo Growth by Planting Mangroves. Port Everglades. https://www.porteverglades. net/articles/post/port-everglades-uplandmangrove-enhancement-trends-for-success/

Levings SC, Garrity SD, VanVleet ES and Wetzel DL. 1997. Sublethal injury to red mangroves two years after oiling. International Oil Spill Conference, American Petroleum Institute.

Maritime Transport. 2016. Corporate Social Responsibility. Maritime. https://www. maritimetransport.com/corporate-socialresponsibility

Nguyen TQN. 2020. Tác động của đại dịch Covid-19 đến thị trường vận tải biên Việt Nam. Tạp chí Tài chính. https:// tapchitaichinh.vn/tai-chinh-kinh-doanh/tac- dong-cua-dai-dich-covid19-den-thi-truongvan-tai-bien-viet-nam-329698.html

Nguyen TT. 2016. An Investigation of the Vietnamese Shipping Industry and Policy Recommendations for Profound Participation into ASEAN Integration. Elsevier. https:// www.sciencedirect.com/science/article/pii/ S2092521216300256

Ocean Economist. 2021. How investors can finance a sustainable ocean economy. Ocean Economist. https://ocean.economist.com/ blue-finance/articles/how-investors-canfinance-a-sustainable-ocean-economy

Ovcina J. 2020. Clean Cargo report: Container shipping's $\mathrm{CO}_{2}$ emissions down in 2019. Offshore Energy. https://www.offshoreenergy.biz/clean-cargo-report-containershippings-co2-emissions-down-in-2019/

PetroVietnam. 2019. "Vai trò cảng biển trong phát triển kinh tế biển". Tạp chí Giao thông Vận tải 324.

Phạm TT, Vũ TP, Phạm ĐC, Đào LHT, Nguyen VT, Hoang NVH, Hoang TL, Đào TLC và Nguyen DT. 2019. Cơ hội và thách thức đối với quản lý rüng ngập mặn tại Việt Nam: Bài học tư các tỉnh Thanh Hóa, Thái Bình và Quảng Ninh. Báo cáo chuyên đề 198. Bogor, Indonesia: CIFOR.

Phạm TT, Hoàng TL, Daod TLC, Ngô HC, Hoàng MH, Hoàng TU, Hoàng TTT, Nông NKN, Nguyễn ĐT, Trương VV, Nguyễn TN. 2020. Dịch vụ và người mua dịch vu môi trường rüng ngập mặn tiềm năng tại Việt Nam - kết quả tù nghiên cứu tại Hải Phòng. Infobrief 287. Bogor, Indonesia: CIFOR.

Reynolds GL. 2019. The multi-issue mitigation potential of reducing ship speeds. Environmental Sustainability Consultants. https://seas-at-risk.org/wp-content/ uploads/2021/03/2019.6.11.-Mitigation-shipspeeds.pdf

Saul J. 2019. Ship industry proposes $\$ 5$ billion research fund to help cut emissions. Reuters. https://www.reuters.com/article/us-shippingenvironment-fund-idUSKBN1YM00D

Saul J. 2020. Shipping's share of global Cácbon emissions increases. Reuters. https:// www.reuters.com/article/us-shippingenvironment-imo-idUSKCN2502AY

Schrooten L, De Vlieger I, Panis LI, Chiffi C and Pastori E . 2009. Emissions of maritime transport: a European reference system. The Science of the Total Environment: 408 (2): $318-23$. 
Selin H and Cowling R. 2018. Cargo ships are emitting boatloads of Các-bon, and nobody wants to take the blame. The Conservation. https://theconversation.com/cargo-shipsare-emitting-boatloads-of-Các-bon-andnobody-wants-to-take-the-blame-108731

Shell and Deloitte. 2020. Greenhouse gas emissions in shipping. The Netherlands: Shell. https:// www.shell.com/energy-and-innovation/theenergy-future/greenhouse-gas-emissions-inshipping.html

Shipmap. 2012. https://www.shipmap.org/

Shingeyuki B, Hung TC and Cohen M. 2014. Studies in Can Gio mangrove biosphere reserve, Ho Chi Minh city, Viet Nam. Tohoko Gakuin University, Can Gio Mangrove Protection Forest Management Board and International Society for Mangrove Ecosystems (ISME). http://www.mangrove. or.jp/img/publications/book_pdf/TR06Technical_6.pdf

Simpson SD, Meekan MG, Larsen NJ, McCauley $\mathrm{RD}$ and Jeffs A. 2010. Behavioral plasticity in larval reef fish: Orientation is influenced by recent acoustic experiences. Behavioral Ecology 21 (5): 1098-1105. doi:10.1093/ beheco/arq117

Stopford M. 2009. Maritime Economics 3e. Routldge. https://www.routledge.com/ Maritime-Economics-3e/Stopford/p/ book/9780415275583?fbclid=IwAR2nE08F_ kN3-gIQA_Uu51WdWL2ZKS25TWZwp7e HiMdtZ0CdoACMC6epN8o

Tam NFY and Wong. YS.1994. Nutrient and Heavy Metal Retention in Mangrove Sediment Receiving Wastewater. Water Sci Technol (1994) 29 (4): 193-200.

Tam NFY, Teresa WYW and Wong YS. 2005. A case study on fuel oil contamination in a mangrove swamp in Hong Kong. Marine Pollution Bulletin 51(8): 1092-1100

Tokio Marine Holdings. 2020. "Các-bon Neutral" in Fiscal 2019. Tokio Marine Holdings, Inc. https://www.tokiomarinehd.com/en/ release_topics/release/k82ffv00000086m1att/20200828_Các-bon_neutral_e.pdf

Trimmer C and Godar J. 2019. Calculating Maritime Shipping Emissions per Traded
Commodity. SEI Brief. Stockholm

Environment Institute. https://www.sei. org/publications/shipping-emissions-percommodity/

Truong HG. 2000. Privatisation of the shipping industry in Vietnam: the benefit, problems and proposals. World Maritime University Dissertations.

UNCTAD, 2020. Maritime profile: Vietnam. https://unctadstat.unctad.org/countryprofile/ maritimeprofile/en-gb/704/index.html

UNFCCC. 2014. Shipping, World Trade and the Reduction of $\mathrm{CO}_{2}$ Emissions. International Chamber of Shipping. https://www.icsshipping.org/wp-content/uploads/2014/08/ shipping-world-trade-and-the-reduction-ofco2-emissions-min.pdf

Unilever. 2021. Các-bon footprint - Now it's personal. Unilever. https://www.unilever. $\mathrm{com} /$ news/news-and-features/Featurearticle/2021/Các-bon-footprints-now-itspersonal.html

United Nations. 2020. Review of Maritime Transport 2020. https://unctad.org/system/ files/official-document/rmt2020ch1_en.pdf.

Viện Hàn lâm Khoa học và Công nghệ Việt Nam. 2020. Tổng quan tình hình nghiên cứu, luận giải về muc tiêu và nhũng nội dung nghiên cứu của đề tài: Ô nhiễm môi truờng biên tù nguôn nước thải luc địa. Viện Hàn lâm Khoa học và Công nghệ Việt Nam. www.imer. ac.vn:8085/homepage.asp

Vidal J. 2009. Health risks of shipping pollution have been 'underestimated'. The Guardian. https://www.theguardian.com/ environment/2009/apr/09/shipping-pollution

Vien NN, Tran VM, Le VK, Nguyen ST, Le TL, Ly T, Margot CK, Marjukka M, Chomcharn A, Jensen M, Issawasopon P. 1993. A Changing Resources System: Case study in Can Gio District, Southern Vietnam. Bangkok, Thailand: FAO. http://www.fao.org/3/ad559e/ ad559e00.pdf

World Ocean. 2021. How investors can finance a sustainable ocean economy. World Ocean. https://ocean.economist.com/blue-finance/ articles/how-investors-can-finance-asustainable-ocean-economy 

Các báo cáo chuyên đề của CIFOR chuyển giao các kết quả nghiên cứu quan trọng đối với ngành lâm nghiệp. Nội dung của báo cáo đều được đánh giá bởi các chuyên gia trong và ngoài tổ chức.

Với tốc độ và ảnh hưởng của biến đổi khí hậu ngày một gia tăng, Ủy ban Liên Hợp Quốc về biến đổi khí hậu cũng như các quốc gia trên thế giới đang kêu gọi sự tham gia tích cực của mọi ngành nghề để giải quyết vấn đề môi trường trên toàn cầu.

Đóng vai trò chủ đạo trong thương mại thế giới khi vận chuyển 90\% hàng hóa trên thế giới, ngành vận tải biển có khả năng đóng góp vào cuộc chiến thích ứng và giảm thiểu tác động của biến đổi khí hậu.

Báo cáo này tìm hiểu những đóng góp cho sự phát triển kinh tế toàn cầu và Việt Nam của ngành vận tải biển vận tải biển, phân tích tác động môi trường mà các hoạt động vận tải biển có thể gây ra, rà soát các giải pháp toàn cầu và Việt Nam đang đưa ra để giải quyết các vấn đề rủi ro môi trường. Đồng thời, báo cáo xem xét vai trò của rừng ngập mặn trong việc hỗ trợ ngành vận tải biển thực hiện các cam kết bảo vệ môi trường và phát triển bền vững.

\begin{tabular}{|c|c|c|}
\hline (1) & $\begin{array}{l}\text { RESEARCH } \\
\text { PROGRAM ON } \\
\text { Forests, Trees and } \\
\text { Agroforestry }\end{array}$ & $\begin{array}{l}\text { Chương trình nghiên cứu CGIAR về Rừng, Cây và Nông lâm kết hợp (FTA) là chương trình nghiên cứu phát } \\
\text { triển lớn nhất trên toàn cầu nhằm nâng cao vai trò của rừng, cây, và nông lâm kết hợp trong phát triển } \\
\text { bên vững, đảm bảo an ninh lương thực và thích ứng và giảm thiểu biến đổi khí hậu. CIFOR điêu phối FTA } \\
\text { và hợp tác với ICRAF, Liên minh đa dạng sinh học quốc tế, CIAT, CATIE, CIRAD, INBAR và TBI. }\end{array}$ \\
\hline CUÁn & & Các nghiên cứu của FTA cũng nhận được sự tài trợ của Quỹ Ủy thác CGIAR: cigar.org/funders/ \\
\hline
\end{tabular}

cifor.org

forestsnews.cifor.org nghiên cứu sáng tạo, nâng cao năng lực của các bên đối tác, tích cực tham gia đối thoại với các bên liên quan để hỗ trợ định hình chính sách và thực tiễn tác động tới rừng và con người. CIFOR là tổ chức nghiên cứu thuộc liên minh CGIAR và chủ trì các chương trình nghiên cứu của CGIAR về Rừng, Cây gỗ và Nông lâm kết hợp (FTA). Trụ sở chính của CIFOR đặt tại Bogor, Indonesia và các văn phòng của CIFOR có mặt tại Nairobi, Kenya; Yaounde, Cameroon; Lima, Peru và Bonn, Germany. 